\title{
3. IMAG (IN)ING KUWAIT FROM ABOVE IN AERIAL PHOTOGRAPHY, URBAN PLANNING, AND CARTOGRAPHY
}

"[Kuwait City] is indeed a town planner's dream," wrote Peter W. Macfarlane, one of the British urban planners responsible for the first master plan of Kuwait. ${ }^{1}$ "To drive along a splendid dual carriageway road, which only a year before was a line on paper, is an experience given to few in this country," he marveled, contrasting the far more restricted planning situation in "this country" (i.e., Britain) with the situation in Kuwait. ${ }^{2}$ Published in 1954, two years into the implementation of the master plan, the comment demonstrates that the projected urban overhaul of the Gulf town focused on the creation of a motorized city in which the new architectural landscapes would be consumed as vistas in a drive-by (or even fly-over) mode in the logic of petro-modernity.

Town planning in the twentieth century relied on new technologies of seeing, evaluating, and representing space. While the ultimate goal was rebuilding Kuwait from scratch, the planning process also gave way to unprecedented and compelling visualizations of the town itself. First of all, a comprehensive aerial survey of Kuwaiti territory was undertaken, which resulted in a composite aerial photomosaic. Second, the country's first master plan, which envisioned a radically new Kuwait City based on the photomosaic as a prime source of information, was developed. In the context of Kuwait's urban visual culture, both the photomosaic and the master plan were new forms of visualization, as they pictured Kuwait in its vertical totality from above for the first time. The urban transformation of Kuwait City during the 1950s was therefore not only a translation from image to physical space as the master plan was implemented, but also the creation of the city in and as pictures that eventually became iconic yet highly ambiguous and ultimately iridescent symbols of Kuwait's petro-modernity.

Petroleum played a decisive role in respect to the technical, visual, and material conditions of seeing and picturing the coastal settlement of Kuwait from above in aerial photography and urban planning. The subsequent dissemination of the vertical

\footnotetext{
1 Peter W. Macfarlane, "Planning an Arab Town: Kuwait on the Persian Gulf”, Journal of the Town Planning Institute 40, no 5 (April 1954): 113. Town planning was used in British contexts at the time; urban planning is the term commonly used today. In the following the terms are used interchangeably.

2 Ibid.
} 
gaze in other visual media (such as modern cartography) and among other audiences established a normative form of representing Kuwait from above. While aerial-view imagery undoubtedly created a new visual identity for Kuwait, it also came to encompass an incommensurable tension between nostalgic affect for the pre-oil town as social habitat and the highly appreciated progressiveness of the oil city as material and visual symbol of its modernization. Unraveling the different readings of the aerial-view imagery in the 1950s and 1960s unlocks the visual strategies that characterize petro-modernity and account for its seductive iridescent effect.

\subsection{Visualizing Kuwait in Aerial Photography}

A short notification, published in the British aeronautic weekly Flight in early June 1951, announced the official commencement of a systematic survey of Kuwait City through aerial photography: ${ }^{3}$

On May 24th a Hunting Aerosurveys expedition left Luton Airport in a Percival Survey Prince, bound for the Middle East territory of the Sheikh Abdulla as-Salim as-Subhah [sic], who has commissioned the company to prepare large-scale photomosaics of Kuwait and the surrounding 95 square miles. ${ }^{4}$

What the text did not communicate was that the photomosaics were to serve as the main source of information for the British town planners Anthony Minoprio, Hugh Spencely, and Peter W. Macfarlane, who were commissioned with creating the first master plan for Kuwait City. It also did not disclose the historical relationship between aerial photography and petroleum prospecting in the Gulf region.

Aerial surveying has been considered vital for exploring remote, difficult to access and/ or vast areas and was especially recommended for "unmapped countries," a term usually applied to developing countries. ${ }^{5}$ Rapidly devised in conjunction with heavier-than-air flight since the early 1900s and first applied in its modern form for the air reconnaissance of Palestine in 1918, aerial photography went through immense professionalization during World War I and World War II as it became a strategical tool of modern warfare

\footnotetext{
3 Flight was first published in January 1909 as the official weekly journal of the Aero Club of Great Britain, which was founded in 1901 and renamed the Royal Aero Club (RAeC) in 1910. The RAeC established itself as the national coordinating body of ballooning and later aviation; until 1915 it also trained most military pilots. The journal was renamed Flight International in 1962. Today, it is considered the foremost aeronautical weekly in the world. See John Blake, "A Brief History of the Royal Aero Club," RAeC Homepage, section "History \& Origins," accessed January 29, 2021, http://www.royalaeroclub.co.uk/history-and-origins.php.

4 “Civil Aviation News," Flight 59, no. 2211 (June 1951), 685.

${ }^{5}$ One of the knowledge hubs to develop surveying technologies for developing countries was the International Training Centre for Aerial Survey (ITC) established in 1950 in Delft. See Willem Schermerhorn, "Planning in Modern Aerial Survey," Photogrammetria 17, no. 1 (1960); W. G. L. de Haas, "Aerial Survey for Developing Countries," Build International, no. 11 (November 1970).
} 
and surveillance. ${ }^{6}$ As a "powerful source of visual knowledge with connotations of control over the physical terrain," aerial surveying has played an important role in the development and control of colonial or quasicolonial territories since its inception. ${ }^{7}$ For example, for the Levant and North Africa, topographic mapping, land registry, military control, archaeological surveys, and the exploitation of resources played a major and often negative role. ${ }^{8}$ After World War I, oil companies and other actors-for example archaeologists, geologists, and eventually town planners-recognized the potential of air surveys to help them in their endeavors. They appreciated this technique for its quick, efficient, and detailed visual documentation of the Earth's surface, which provided an unprecedentedly rich set of information that was invaluable to anyone trained to interpret the aerials. ${ }^{9}$

According to William Facey and Gilian Grant, authors of Kuwait by the First Photographers, an oblique photograph taken in 1927 (probably as part of a series) is considered to be the earliest aerial record of Kuwait (fig. 3.1). ${ }^{10}$ This photo was shot in the context of a British survey of the Persian Gulf that sought to find suitable landing spots for the air route to India. ${ }^{11}$ The 1927 photo was taken from the seaside and depicts the harbor front, one of the big cemeteries, Safat Square, and substantial parts of the intra muros settlement. More obliques followed when a squadron of the British Forces in Iraq took photographs of Kuwaiti territory in December 1934 that included "the Town and the existing landing ground, also the site of the flying boat moorings and the site proposed for the new landing ground." ${ }^{12}$

${ }^{6}$ Frank Scarlett, "The Application of Air Photography to Architecture and Town Planning," Journal of the Royal Institute of British Architects 53, no. 8 (1946): 319. In recent years, Eyal Weizman and the team at Forensic Architecture have revisited the early aerial reconnaissance of Palestinian territory in light of contemporary political conflicts, which indicates the ongoing influence of such (historical) imagery not only in Kuwait but in other parts of the world, too. See Eyal Weizman and Fazal Sheikh, The Conflict Shoreline: Colonization as Climate Change in the Negev Desert (Göttingen: Steidl, 2015).

7 Tanis Hinchcliffe, “The Synoptic View': Aerial Photographs and Twentieth-Century Planning”, in Camera Constructs: Photography, Architecture and the Modern City, ed. Andrew Higgott and Timothy Wray (Farnham: Ashgate, 2012), 135; Beaumont Newhall, Airborne Camera: The World from the Air and Outer Space (New York: Hastings House, 1969), 51.

${ }^{8}$ Scarlett, “The Application of Air Photography to Architecture and Town Planning," 323. See also Karen L. Piper's chapter on "Air Control, Zerzura and the Mapping of the Libyan Desert," in Karen L. Piper, Cartographic Fictions: Maps, Race, and Identity (New Brunswick: Rutgers University Press, 2002), 95-127.

${ }^{9}$ For an excellent overview of the proliferation of aerial photography in the US, see Roger E. Bilstein, Flight in America: From the Wrights to the Astronauts, rev. ed. (Baltimore: Johns Hopkins University Press, [1984] 1994).

${ }^{10}$ See Facey and Grant, Kuwait by the First Photographers, 24.

11 Ibid., 23.

12 Air Headquarters, British Forces in Iraq, to Political Resident, Bushire, July 24, 1934, and Political Agency, Kuwait, to Air Headquarters, British Forces in Iraq, January 21, 1935, both in "Air Photographs of Kuwait and Aerial Reconnaissance," file 6/11, 1934-1948, IOR/R/15/5/287, India Office Records and Private Papers, 


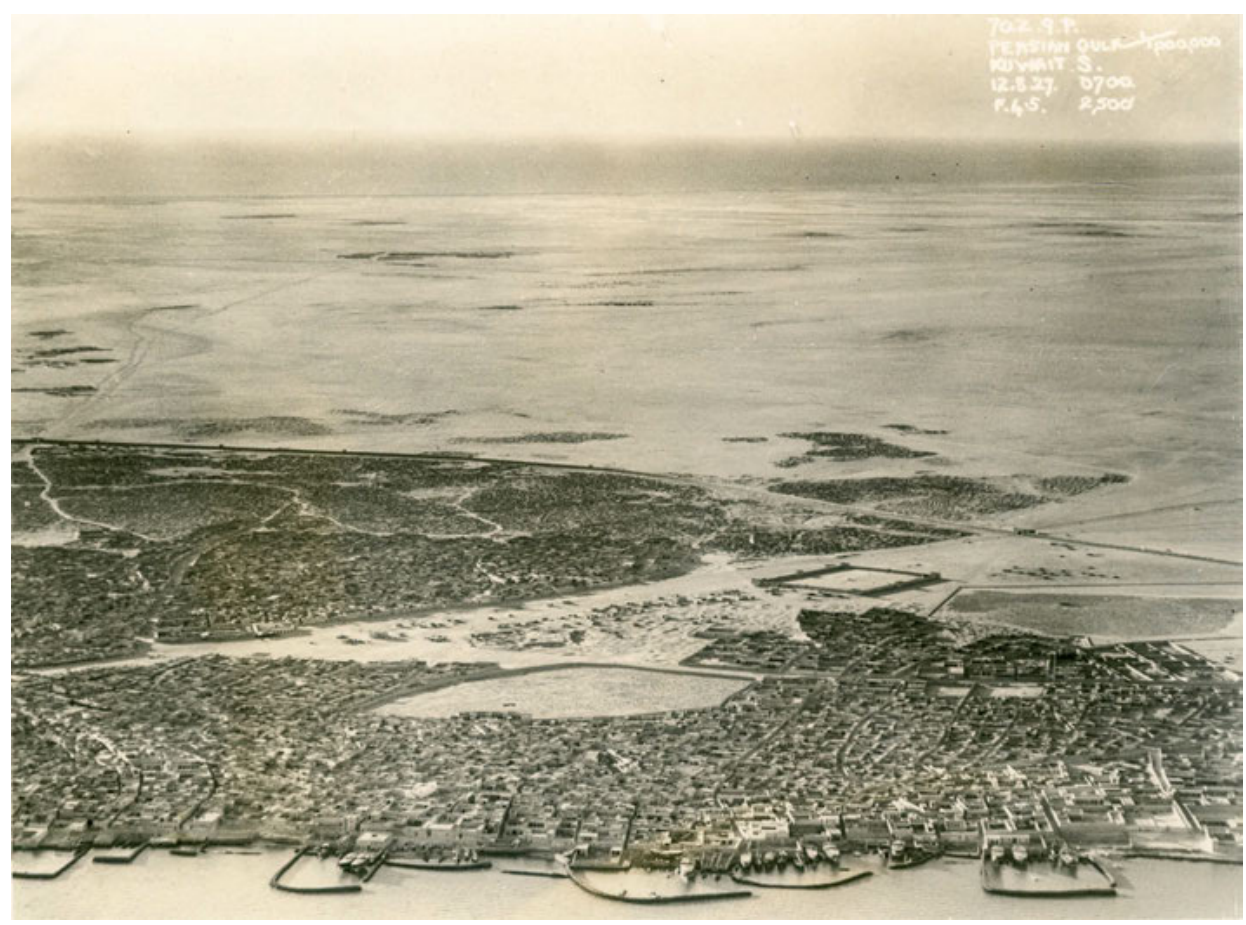

3.1 Aerial view of Kuwait Town. Photograph taken on August 12, 1927.

In contrast to these early sporadic oblique photos of the town of Kuwait, the exhaustive 1951 aerial survey was a novel approach. In its zeal to systematically and comprehensively explore Kuwait it was far more similar to the surveying approaches that oil companies applied to petroleum prospecting in the region. In fact, most of the aerial imagery of the Gulf taken before aerial photography, which became an essential tool in the modern town planning of Gulf cities from the midtwentieth century onward, had resulted from petroleum surveying. ${ }^{13}$ Similarly, in the US after World War I, the oil industry was the commercial sector that dominated the use of aerial photography for geological prospecting. ${ }^{14}$ In Canada and Alaska, oil exploration was also greatly dependent on aerial surveying. ${ }^{15}$ In the 1930s, oil companies like the Shell group invested substantially in improving methods of aerial geology through photographic visualization technologies

British Library. Apparently, Shaykh Ahmad, then ruler of Kuwait, was pleased to receive a copy, but the photographs are not included in the British archival documents.

${ }^{13}$ See Scarlett, "The Application of Air Photography to Architecture and Town Planning," 320.

14 Bilstein, Flight in America, 68.

${ }_{15}$ Matt Dyce, "Canada between the Photograph and the Map: Aerial Photography, Geographical Vision and the State," Journal of Historical Geography 39 (2013): 69; on the contemporary entanglement of oil and aerial 
to tap petroleum deposits in unexplored territories such as New Guinea. ${ }^{16}$ In the Gulf, Hunting Aerosurveys emerged as the leading firm to fly aerial surveys over vast areas of today's Iran, Iraq, and the Arabian Peninsula for oil prospecting during the first half of the twentieth century. The view of Kuwait-from-above that Hunting Aerosurveys and its predecessor companies enabled thus intersected with petroleum (prospecting) in multiple ways.

\section{Hunting Aerosurveys and the Petroleum Industry}

The London-based company had multiple relationships with petroleum. It belonged to the Hunting Group, a leader in the field of commercial aerial photography, surveying, and film, but it was also a shareholder in the oil industry. ${ }^{17}$ Prior to establishing Hunting Aerosurveys in 1942, the Hunting Group merged with the Aircraft Operating Company (AOC), which included the British company Aerofilms as a subsidiary. Registered in May 1919 by former Royal Air Force pilots Francis L. Wills and Claude Grahame-White, Aerofilms was one of the pioneers of commercial aerial photography, comparable only with Fairchild Aerial Surveys, founded by Sherman Fairchild in the US in $1920 .{ }^{18}$ By 1929 , the AOC had already undertaken various aerial surveys in Iraq, Brazil, and Southern Rhodesia on behalf of governments and private companies, and advertised its services for "empire development." 19 During the 1930s, the Anglo-Persian Oil Company (APOC) commissioned the company to fly aerial surveys over Persia. ${ }^{20}$ In the course of World War II, the Air Ministry requisitioned the AOC to execute military air reconnaissance, interpretation of aerial photography, and mapping. By the end of the war, when the AOC (including Aerofilms) had become part of Hunting Aerosurveys, the company started offering commercial aerial photography for civilian services such as town planning and geological surveys. The sudden shift of customer orientation according to war or peace

surveying see Ila Tyagi, “Spatial Survey: Mapping Alaskan Oilfield Infrastructures Using Drones," Synoptique 8, no. 1 (2018).

${ }^{16}$ The "Bataafsche Petroleum Maatschappij," part of the Shell Group, undertook aerial prospecting for oil in New Guinea from 1935 to 1937; see Justus Krebs, “The Application of Aerial Geology and Aero-Photogrammetry in Petroleum Exploration," Photogrammetria 4, no. 2 (1941). On Justus Krebs, a Swiss geologist who was one of the pioneers of developing aerial geology and photogrammetry for oil exploration, see E. Ritter, "Nachruf: Krebs, Justus," Verhandlungen der Schweizerischen Naturforschenden 193 (1959).

${ }^{17}$ For a list of companies within the Hunting organization, see Aerofilms and Aero Pictorial, Classified Index to the Library of Aerial Photographs, rev. ed. (London: A Hunting Group Company Publication, [1954] 1962).

${ }_{18}$ Denis Cosgrove and William L. Fox, Photography and Flight (London: Reaktion, 2010), 46.

19 Aircraft Operating Company, “Aerial Survey and Empire Development," ca. 1929, 68783, BP Archive, University of Warwick.

${ }^{20}$ In March 1940, the AOC supplied the War Office with aerial mosaics and individual vertical prints that the oil company had commissioned. See Military Protection of AIOC Interests in Iran, 1935-1940, 58997, BP Archive, University of Warwick. 
time was typical for this area of business. Meanwhile, Aerofilms continued under its original name and specialized in oblique photography.

Continuing the AOC's prewar engagement, Hunting Aerosurveys quickly received commissions from oil industries operating in the Middle East and Latin America. ${ }^{21}$ For example, the company conducted "aerial exploration of large areas of the uncharted mountains and deserts in Iran” for the Anglo-Iranian Oil Company between 1946 and 1949 and announcements such as "10,000 sq Miles Air Survey" in search of potential oil fields appeared frequently in Flight throughout this period. ${ }^{22}$ The Kuwait Oil Company archives also hold various obliques approximately dated to the second half of the 1940s, which were probably taken by the company in the context of the start of oil exports in 1946. ${ }^{23}$ British archival sources indicate that Hunting Aerosurveys conducted aerial surveys on the Iraqi/Kuwaiti frontier in preparation for potential new pipeline tracks and locations of pumping stations for the Kuwait Oil Company (KOC) around August $1948 .^{24}$ Eventually, the KOC acquired the necessary surveying equipment itself. In the late 1950s it owned a Viscount airliner and two Twin Pioneers, the latter a model often used for aerial prospecting. The company flew surveys on behalf of the Kuwaiti Public Works Department to document the urban development of Kuwait; ${ }^{25}$ however, none of these surveys were as comprehensive as the one undertaken by Hunting Aerosurveys in May 1951. The history of Hunting Aerosurveys' engagement in the Arabian Peninsula provides a case in point that aerial photography arrived in this region along with the pursuit of petroleum by international oil companies.

Petroleum also played a decisive role in the development of aerial surveying on a material level. For example, the type of airplane used over Kuwait in May 1951 was a Percival Survey Prince (fig. 3.2). This all-metal twin-engine high-wing monoplane had been modified for aerial surveying with a lengthened transparent nose and by inserting two camera hatches covered by removable transparent panels in the fuselage. ${ }^{26}$ With this setup, the photographer shot photos of potential oil-bearing grounds by remote control

\footnotetext{
21 “Hunting Aerosurveys," Flight 51, no. 1994 (March 1947): 216.

22 “Civil Aviation News: 10,000 Sq Miles Air Survey," Flight 52, no. 2035 (December 1947): 727; "Here and There: Oil Survey in Iran,” Flight 54, no. 2084 (December 1948): 652-53; “Civil Aviation News: Surveying for Oil," Flight 56, no. 2129 (October 1949): 499.

${ }^{23}$ KOC Archive, Ahmadi, photographic holdings; see also Facey and Grant, Kuwait by the First Photographers, 29.

${ }^{24}$ List of air photographs recently taken at Kuwait, August 24, 1948, in John M. Pattinson, Kuwait: General (Photographs), 1946-1949, 59735, BP Archive, University of Warwick; Pattinson, AIOC London, to Southwell, KOC Ahmadi, January 4, 1949, in John M. Pattinson, Kuwait: General, 1946-1949, 59735, BP Archive, University of Warwick.

${ }_{25}$ Town Office monthly report, August 1958, Town Office, 1957-1958, 106975, BP Archive, University of Warwick. On KOC aircrafts see Rodney Giesler, “Memories of Kuwait 1958-1961," file 1/1, GB165-0508, Rodney Giesler Collection, Middle East Centre Archive, St Antony’s College, Oxford.

26 "Specialist Princes: New Variants of Percival Feederliner for Survey and Military Training," Flight 56, no. 2128 (October 1949): 476-77; “The Survey Prince," Flight 57, no. 2146 (February 1950): 196-97.
} 
3.2 A Percival Survey Prince on the cover of Flight magazine, March 7, 1952.

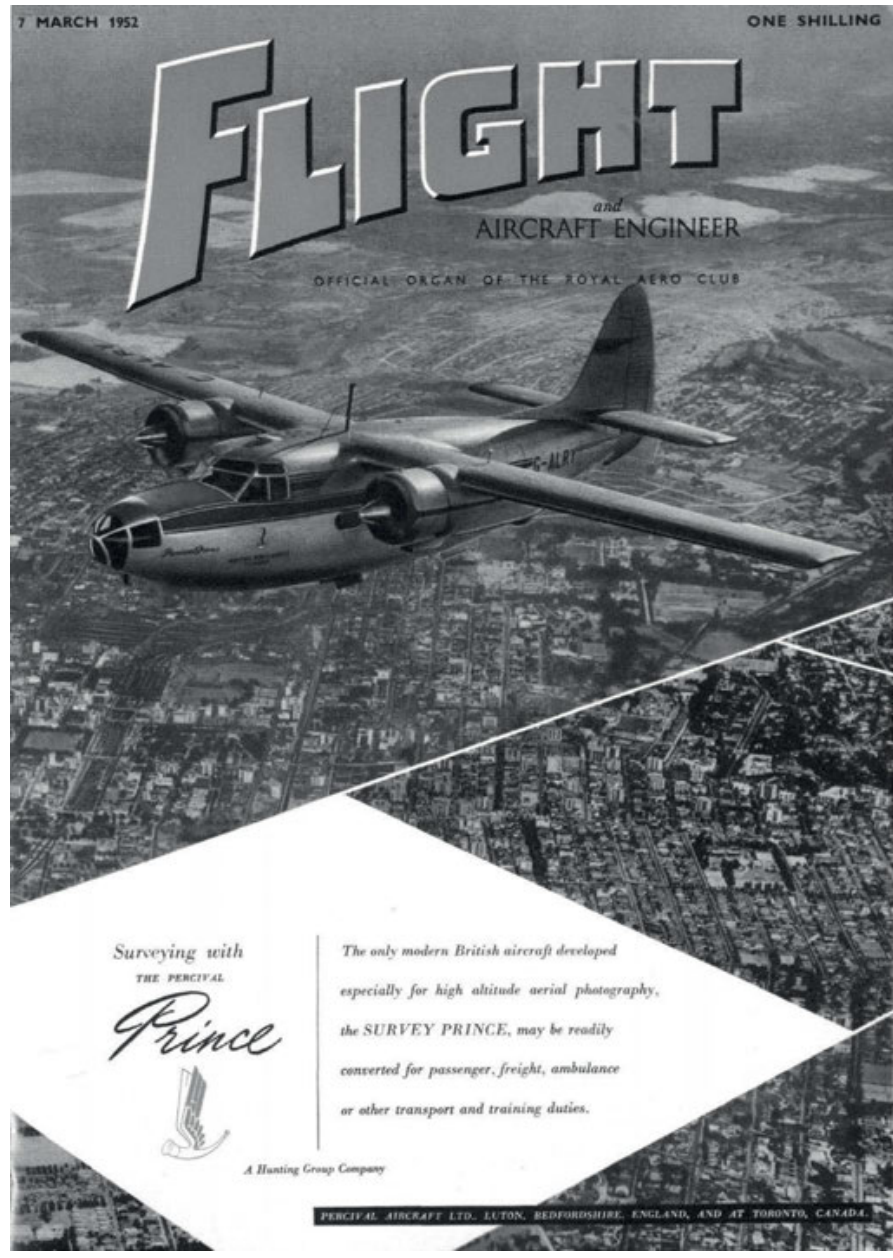

while looking through transparent thermoplastic window screens made of Perspex, a petroleum-based polyacrylate derived from natural gas. ${ }^{27}$ The airplanes ran, of course, on kerosene. Last but not least, chemicals used to produce film rolls and to develop the photographs usually contained petroleum derivatives. The fact that aerial photography depended materially and technologically on petroleum-derived products underscores this visualizing technology's intrinsic entanglement with the fossil material.

\footnotetext{
${ }^{27}$ Perspex was used in the aviation industry because of its clarity, stability, and thermo-resistance.
} 


\section{Kuwait from Above in 1951}

For the 1951 Kuwait survey, Hunting Aerosurveys covered an area roughly equal to the total area of Kuwait City today (ca. 200 square kilometers) and produced both oblique and vertical aerial photographs. Obliques are aerials taken by a camera aimed at the ground at an angle of various degrees, like the 1927 aerial shot of Kuwait. They sometimes include the horizon (high oblique), which offers a more three-dimensional view. For verticals, the camera is directed perpendicularly toward the ground, creating photos with hardly any depth. In contrast to earlier oblique aerials that had shown only certain parts of Kuwait town, the novelty of the 1951 photomosaic was that it presented a composite vertical view of the town of Kuwait and its surroundings as a whole (fig. 3.3).

Generally speaking, a photomosaic is "any combination in more or less permanent mounted form of two or more vertical photographs." ${ }^{28}$ Rectified, scaled, and assembled, the vertical photographs "quilt together a view of landscape." ${ }^{29}$ The process of aerial surveying to generate verticals can be imagined as a macroscopic scanning process by an airplane. While the specially-equipped plane flies over the designated territory in adjacent parallel routes (or stripes), several cameras directed perpendicularly to the ground take photographs released by an automatic shutter on a continuous role of film. Ideally, each photograph overlaps with the adjacent ones by at least 30 percent. Thereby, each point on the ground is covered from at least two different angles, which enables a stereoscopic three-dimensional view. Two different media can subsequently be developed from verticals: photomosaics and maps.

Maps are produced by enriching the composite photo with additional topographic information from ground control, which in the case of Kuwait was provided by the Public Works Department. From this information it is possible to develop proper topographic maps in the form of line drawings. In contrast, the photomosaic (a composite picture) is rich in nuanced photographic information, but its content is not matched with additional sources, and therefore more ambiguous in its interpretation. Nevertheless, the 1951 photomosaic showed the built-up totality of the town in total perpendicularity reminiscent of modern topographic map standards that translated a lived environment into a fossil-fueled image.

The large-scale composite photograph of the town of Kuwait that was assembled from verticals taken in May 1951 visually encompasses part of Kuwait Bay, the town of Kuwait, and a substantial part of the area outside the town wall, where some urban sprawl was already visible in 1951 (see fig. 3.3). The photomosaic therefore does not include the complete surveyed area, but instead focuses on the town in line with its function to support town planning. The total landmass makes up around three quarters of the

${ }^{28}$ Melville C. Branch, Jr., Aerial Photography in Urban Planning and Research, Harvard City Planning Studies 14 (Cambridge, MA: Harvard University Press, 1948), 75. Photographs that are pasted together by eye measure form a so-called uncontrolled mosaic.

${ }^{29}$ Dyce, "Canada between the Photograph and the Map," 76. 
3.3 The 1951 photomosaic of aerial photographs of Kuwait, taken in May that year by Hunting Aerosurveys.

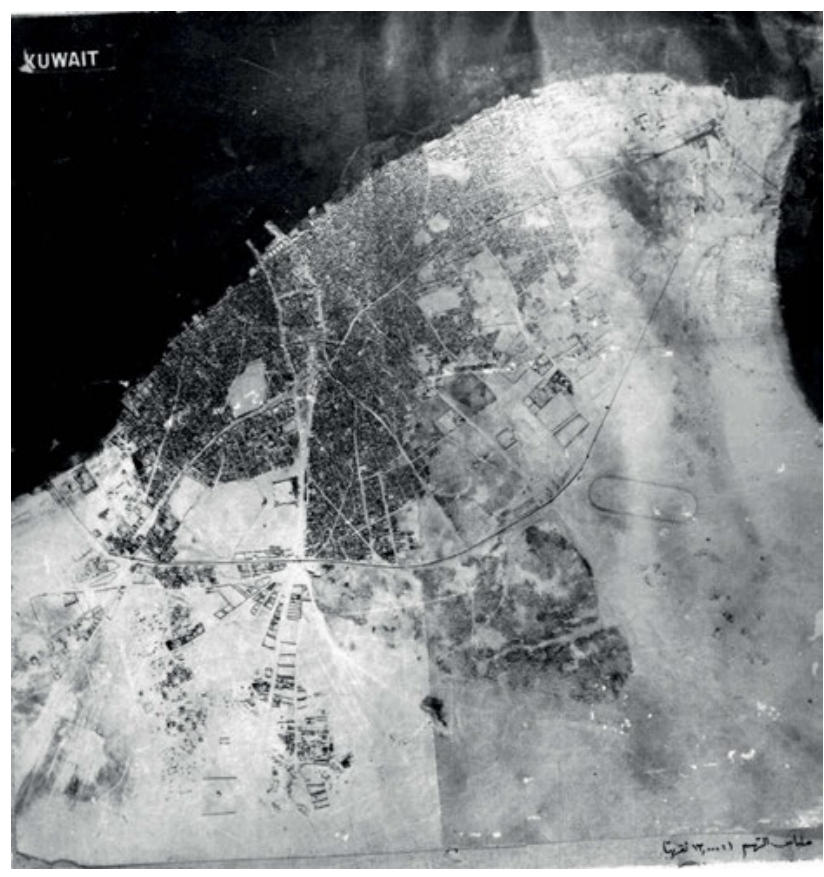

image, its various shades of gray contrasting with the surface of the sea, which appears in darker grays and even black. This stark black-and-white contrast makes the shape of the coastal land formation emerge prominently against the dark "background" of the sea and introduces the characteristically pointed shape of Kuwait City: the country's topography at this coastal section is shaped like a wave pointing right while the walled off town expands along the upper left of the wave crest and toward the inside of the wave, forming an almond-like shape.

"Kuwait" is written in typewritten capital letters in the upper left corner of the composite image and "scale of picture approximately 13,000" is handwritten in Arabic in the bottom right corner. By means of the integrated writing, the aerial image is aligned along the north-south axis and thus already organized according to modern topographic map standards. Depending on the accuracy of the photographs' alignment, the outcome is a picture disguising its composite nature to the viewer. Taken from a great height, the aerial perpendicular view flattens, abstracts, and formalizes real, physical, and urban space. For the untrained eye, it reduces the (urban) landscape to shapes and colors, to a single black-and-white image. The perpendicular verticality produces the flatness of space typical of modern cartography, which translates and subjugates a lived environment (in)to a measurable, easily controllable, and homogenous visual representation of space.

Aerial photography is a petro-fueled technology that objectifies space by turning it into pictures. This specific photomosaic amalgamates many hours of flying strips over the 


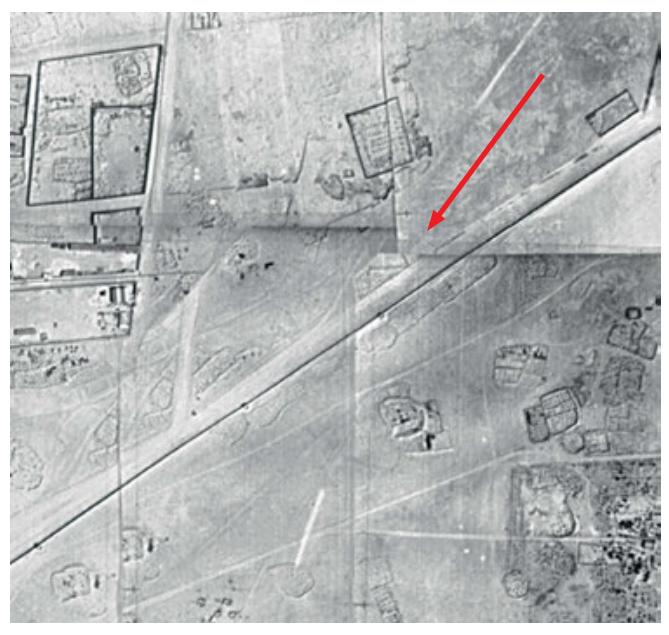

3.4 Detail of the 1951 photomosaic of aerial photographs of Kuwait with arrow indicating the edge of overlapping photographs.

territory and thus many different technically enhanced viewpoints into one photograph. The physical photo-collage still allows each photograph to be dissected from the others, thus disclosing its composite nature and the artificiality of its viewpoint (fig. 3.4). Later copies, images of the photo-collage, however, no longer provide for this physical and visual differentiation of the photographic mosaic stones. By way of bringing these multiple standpoints and timelines into one homogenous picture, the viewer is presented with an overwhelming yet condensed view that is humanly impossible to achieve. Nevertheless, the photographic image acts as apparent proof that it is in fact possible. Aerial photographs are fascinating as they convey the sense of looking at a miniature version of the world, which can convey to the viewer a feeling of total control. The fossil-fueled photomosaic synthetizes the world as a picture; an iridescent picture that depends on an artificial but extremely powerful and seductive position of unlimited vision. Here, the iridescent effect encapsulates the ambition to hide its multiple eyes, its composite nature, its fossil-fueled technical apparatus, and its specific temporality from view.

Aerial photography also becomes a powerful strategy to disembody lived space. On the one hand, it decouples images from their optical apparatus, economic-political interests, and the human bodies flying over Kuwait producing these images. On the other hand, it empties the urban space of the people, cultural narratives, and social experiences situated within it. Through aerial photography and the view from above, the urban space undergoes a petro-fueled optical and aesthetic translation. Simultaneously to the process of disembodiment, a space that is unfamiliar to the technicians and experts in charge of the seeing process is turned into a familiar visual representation for this professional viewership. As a result, aerial photos entail both the defamiliarization of space for people used to experiencing this particular space as lived environment and the familiarization of this space for people used to working with urban space in an abstract, external mode. 
Once translated, disembodied, and objectified as urban-space-as-image, the image can now be modified as needed. This in turn gives way to an unrestricted vision that allows one to alter the depicted space as one pleases, as, for example, for town planning purposes. In her essay "Situated Knowledges: The Science Question in Feminism and the Privilege of Partial Perspective," Donna Haraway argues that if enhanced vision (as sight) is not openly situated as still somewhat individually embodied, technically mediated, and politically situated knowledge, it plays what she calls "the god trick." What she criticizes is that "the eyes have been used to signify a perverse capacity-honed to perfection in the history of science tied to militarism, capitalism, colonialism, and male supremacy-to distance the knowing subject from everybody and everything in the interests of unfettered power." ${ }^{30}$ Similar to Foucault's analysis of the panopticon as a mechanism of surveillance, Haraway argues that this total view from above "[claims] the power to see and not be seen, to represent while escaping representation." 31 To understand how the god trick worked in the case of Kuwait it is necessary to trace the dissemination of the photomosaic and its pervasive aerial view in visual culture and to disclose the ways in which both the pre-oil town of Kuwait and the urban transformation were negotiated visually.

\subsection{Envisioning Kuwait in Urban Planning}

In 1951, three London-based town planners-Anthony Minoprio, Hugh Spencely, and Peter W. Macfarlane-received the assignment to conceptualize a development plan to modernize Kuwait. As their understanding of the existing town was based almost exclusively on the aerial imagery of May 1951, and thus on this particular view from above, their 1952 Master Plan projected what they called "New Kuwait City" on top of this flattened, abstracted, objectified, and "rationalized" vertical representation of Kuwait's existing urban space.

This planning commission formed one of the goals of Abdullah al-Salem Al Sabah's modernization reform for Kuwait in the early 1950s, which was nothing less than creating "the finest city in the Middle East and the happiest State." ${ }^{32}$ He thereby placed the urban transformation of the coastal town of Kuwait at the center of his internal politics. His enthusiasm for the comprehensive urban development of Kuwait was initially not spurred by establishing an independent nation-state as part of decolonization or postwar reconstruction, as had been the case for many other countries rebuilding their capitals in the 1950s. Rather, the growth of Kuwait's oil industry-and the subsequent revenues reaching its ruler-provided both the economic means as well as the political independence

\footnotetext{
${ }^{30}$ Donna Haraway, "Situated Knowledges: The Science Question in Feminism and the Privilege of Partial Perspective," Feminist Studies 14, no. 3 (1988): 581.

31 Ibid.

32 “Preliminary Report on Development of Kuwait State," February 13, 1952, Kuwait State Development Board, file 101, 1952, FO 1016/217, The National Archives of the UK.
} 
from the Kuwaiti merchant families required to steer urban reform at such a scale. Moreover, in line with British political aspirations in Kuwait, "it was also important that the city visually reflect the country's newfound prosperity and modernity-something the existing pre-oil landscape failed to do." ${ }^{33}$ The reason for this was that the pre-oil landscape did not contain any established markers of this modernization trajectory as mentioned before, for example fossil-fuel based motorization and air-conditioned architecture, but it was also a shift that was expressed in new building typologies, industrially produced building materials and different architectural styles.

As scholars have rightly pointed out, combined with the rhetoric of modernization and the promotion of foreign expertise, architecture's and urban planning's primary use often came "to represent progress" within the Persian Gulf and in many other localities of the MENA region. ${ }^{34}$ The plausibility of the success story depended not only on physical proof established by the material alteration of the built environment but also on visual proof. Esra Akcan highlights that it was especially "the canonic buildings and master plans of the 1950s and early 1960s [that] were perfect participants in modernization theory," since they served as not only material but also visual currency because they circulated as portable, reproducible images. ${ }^{35}$ Shaping the built environment under Shaykh Abdullah's name provided-among other things-the opportunity to cement his personal power and the position of the House of Sabah within internal and external networks. ${ }^{36}$

\section{The Politics of Commissioning the First Master Plan of Kuwait}

Initially, Shaykh Abdullah had intended to engage a Palestinian town engineer for Kuwait's transformation; however, Herbert G. Jakins, the British Political Agent to Kuwait between 1948 and 1951, persuaded the ruler to consider a British expert. ${ }^{37}$ Eventually, early in 1951, Shaykh Abdullah asked H. T. Kemp, his representative to the Kuwait Oil Company (KOC) in London, to find a suitable British town planner for Kuwait City. ${ }^{38}$

\footnotetext{
33 Al-Nakib, Kuwait Transformed, 98-99.

${ }^{34}$ Karimi and Kim, “On Protectorates and Consultanates," 90; see also Panayiota I. Pyla, ed., Landscapes of Development: The Impact of Modernization Discourses on the Physical Environment of the Eastern Mediterranean (Cambridge, MA: The Aga Khan Program at the Harvard University Graduate School of Design, 2013). ${ }^{35}$ Esra Akcan, "Global Conflict and Global Glitter: Architecture of West Asia (1960-2010)," in A Critical History of Contemporary Architecture: 1960-2010, ed. Elie Haddad and David Rifkind (Farnham: Ashgate, 2014), 313.

${ }^{36}$ On the delicate balancing of power between the ruler and the merchants in the early 1950s, see Al-Nakib, Kuwait Transformed, 91-94.

${ }^{37}$ Jakins to Sir Rupert Hay, Political Resident in the Persian Gulf, January 2, 1951, FO 371/91270, reprinted in Richard Trench, ed., Arab Gulf Cities: Kuwait City, 4 vols. (Cambridge, UK: Archive Editions, 1994), 545.

${ }^{38}$ Ibid., 546. "Mr. Kemp was appointed under the Oil Concession as the Ruler's London representative with the Kuwait Oil Company. He has at present no official position vis-à-vis the Foreign Office and it was intended that he should deal exclusively with oil affairs... . In fact, however, he has come to be used more and
} 
Appointing a British planner had ramifications that reached well beyond the walls of Kuwait City. Even though the British-Kuwaiti Protection Agreement of 1899 ensured that Britain's political relationship with Kuwait was constrained to foreign policy only, the commissioning of the first master plan for Kuwait City was deeply entangled in British imperial politics in the Persian Gulf and, on a larger scale, in modernization and development ideologies prevailing at the time. Advisors and experts in particular were the point of entry for British interests in Kuwait; the information and influence they gained allowed the British government to (directly or indirectly) guide important decision-making processes. Rather than providing capital, which Kuwait did not need anyway, posting "circulating experts" who made specialist knowledge portable and mobile had become "a common strategy of Cold War technopolitics." ${ }^{39}$ On the Kuwaiti side, it was perhaps Britain's good reputation in town planning that made it plausible for Shaykh Abdullah to accept British town planners as urban experts. From a British perspective, securing this post for a British company as well as being involved in one of the biggest development projects in Kuwait-its urban transformation-was strongly politically and economically motivated. ${ }^{40}$ It also had symbolic significance: by providing British expertise to Kuwait for a process of social and physical betterment (as urban planning was widely regarded), the British government could foster a positive image of their involvement in the Gulf. Similarly, Kuwait's ruler was able to do the same toward both his community and an international audience, fueling the petroleum promise, rather than being seen as using the oil revenues only for his private enjoyment. ${ }^{41}$

The correspondence between Sir Rupert Hay, Political Resident in the Persian Gulf from 1946 to 1953, Herbert G. Jakins, and the Foreign Office in London reveals that Kemp, encouraged by the Foreign Office, contacted the Colonial Office and the Ministry of Local Government and Planning in London, which suggested the British town planners Anthony Minoprio, Hugh Spencely, and Peter W. Macfarlane for the job. ${ }^{42}$ Alternative town planners and consultant firms had been considered, but Kemp did not

more as the Agent for the Ruler of Kuwait in this country in a variety of matters, quite unconnected with oil, such as commercial transactions and the appointment of experts." C. M. Rose, Kuwait Government Agent in London: Mr. Kemp minutes, January 8, 1952, Recruitment of Experts for Kuwait Development, file 1052, 1951, FO 371/91271, The National Archives of the UK.

${ }^{39}$ Donna Mehos and Suzanne Moon, "The Uses of Portability: Circulating Experts in the Technopolitics of Cold War and Decolonization," in Entangled Geographies: Empire and Technopolitics in the Global Cold War, ed. Gabrielle Hecht (Cambridge, MA: MIT Press, 2011), 43-44.

${ }^{40}$ Gardiner, Kuwait, 33.

${ }^{41}$ See Stephan V. Ward, “Transnational Planners in a Postcolonial World," in Crossing Borders: International Exchange and Planning Practices, ed. Patsy Healey and Robert Upton (London: Routledge, 2010), 50.

${ }^{42}$ The Ministry of Local Government and Housing had just been formed in January 1951 as the central institution for organizing town planning in Britain. Its creation merged functions like housing and local government that had formerly been part of the Ministry of Health and the Ministry of Town \& Country Planning. 
approve of them. ${ }^{43}$ Interestingly, all of the candidates under discussion had been taught at the Liverpool School of Architecture, one of the most influential and internationallyrenowned university-based programs for architecture in Britain then headed by Charles Herbert Reilly. ${ }^{44}$ This possibly indicates that suggestions were made from within this network, although British archival sources do not reveal who within the ministry in fact recommended Minoprio, Spencely, and Macfarlane (MSM) for the Kuwaiti job.

From the British perspective, besides fitting the "portable experts" brief, the evaluation of MSM's skills (as one of the possible selection criteria) is crucial for understanding the commission. In March 1951, Leslie A. C. Frey of the Foreign Office in London wrote to Hay:

Kemp has been in touch, by our arrangement, with the Ministry of Local Government and Planning and after discussing requirements with them was advised to approach a firm of Town Planners named Minoprio, Spencely and Macfarlane. He has since seen all three partners in this firm and seemed to have been impressed with their enthusiasm and by reports he has received from the Development Officers of various towns which they have planned in this country, although we understand that they have had no previous experience of planning overseas. At all events, the three partners in the firm are anxious to visit Kuwait together, so that they will all be aware of the sort of problems they will have to tackle. We understand that Kemp has recommended to the Ruler that he should invite them to Kuwait for a fortnight towards the end of April, when all three can make themselves available at the same time. If the Ruler considers them suitable they would go ahead with the making of plans and then, individually or together, pay such other visits to Kuwait as may later be necessary. ${ }^{45}$

Apparently, Kemp selected these three town planners based on their enthusiasm as well as their experience and expertise with town planning in Britain. Their lack of experience in planning overseas was acknowledged but not given much weight in the decision. Rather, Frey stressed their willingness to visit Kuwait as a positive sign of their keen interest to tackle Kuwait's urban "problems," a phrasing clearly taken from development discourse. ${ }^{46}$ Their selection, despite the fact that they had neither any prior knowledge of or expertise in Kuwait or the Persian Gulf or other British (quasi-)colonial spaces nor any

\footnotetext{
${ }^{43}$ For example, Group I Limited consisted of consultants and construction engineers but lacked a town planner; furthermore, they would have wanted to collaborate with William Holford, professor of town planning at University College, London, who was apparently too busy at the time. Maxwell Fry and Jane Drew, a British architect-planner partnership of international acclaim, were also discussed. However, "nothing seems to be known here of Mr. Maxwell Fry," as Jakins remarked, and their engagement was not pursued further for reasons unknown. Jakins to Hay, March 10, 1951, EA 1052/19, reprinted in Trench, Arab GulfCities, 550. ${ }^{44}$ Maxwell Fry (B.Arch. 1923), Anthony Minoprio (B.Arch. 1925, M.A. 1928), Hugh Spencely (B.Arch. 1926, Certificate of Civic Design 1928) and William Holford (B.Arch. 1930). See Joseph Sharples, ed., Charles Reilly \& the Liverpool School of Architecture 1904-1933 (Liverpool: Liverpool University Press, 1996).

${ }_{45}$ Frey to Hay, May 21, 1951, EA 1052/19, reprinted in Trench, Arab Gulf Cities, 551.

${ }^{46}$ On the terminology of the "problem" in development discourse see Arturo Escobar, Encountering Development: The Making and Unmaking of the Third World (Princeton: Princeton University Press, 1995), 6. Joseph Sharples also portrays Reilly (Minoprio's and Spencely's teacher in Liverpool) as someone who enthusiastically encouraged his students to undertake projects they had not trained for. See Joseph Sharples, "Reilly and
} 
knowledge of Arabic, is reflective of the postwar shift which favored "portable experts" and "gave portable knowledge a higher priority than place-based knowledge (which might include local or indigenous knowledge) for many institutions." ${ }^{47}$ Consequently, MSM's understanding of Kuwait City, as formulated in their subsequent town planning report of November 1951 and the master plan of May 1952, obviously derived predominantly from their town planning education and experience in Britain which was supplemented with their visits to Kuwait (April and July 1951) and the first-hand information they received there, as well as from the aerial survey of May 1951.

The town planners also recognized that two visits and the aerial survey as the core of the (visual) information and site-specific experience on Kuwait available was scarce. Anthony Minoprio himself explained in an interview conducted by fellow British architect Stephen Gardiner in the 1980s: "It was a difficult commission. We didn't know anything much about the Muslim world and the Kuwaitis wanted a city-they wanted a new city, hospitals, schools, housing and good communications... . All we could give them, was what we knew." ${ }^{48}$ Acknowledging that their expertise lay elsewhere, the town planners resorted to aerial photography and visualization strategies typical of mid-twentieth century urban planning in order to provide a modern city by turning the unfamiliar space of Kuwait into a familiar picture-an aerial map-like view from above and a master plan. The special popularity of aerial photography among urban planners resulted from its perceived ability to provide an almost omniscient overview that allowed space to been seen primarily as a planning resource.

\section{Aerial Photography as an (Omniscient) Urban Planning Tool}

British architects and town planners had discussed aerial photography's potential both enthusiastically and skeptically since its introduction to the field in the interwar period. In general, aerials provided a quick, efficient, and seemingly objective means of photographically documenting topographies, both natural landscapes and built-up areas. Thus, depending on the kind of aerials taken, aerial surveys could support the planning and building process before, during, and even after its completion. At that time, oblique photographs were already attributed with a greater "pictorial" potential as they provided the volume of buildings in perspective, while verticals were considered "cartographic." ${ }^{49}$ Town planners in Britain had begun analyzing aerial and especially vertical photographs

His Students, on Merseyside and Beyond," in Charles Reilly \& the Liverpool School of Architecture 1904-1933, ed. Joseph Sharples (Liverpool: Liverpool University Press, 1996), 39.

47 Mehos and Moon, "The Uses of Portability”, 68.

${ }^{48}$ Gardiner, Kuwait, 33-35 (italics in the original).

49 Jack Whittle, “The Use of Air Photographs: Examination and Interpretation," in Town and Country Planning Textbook: An Indispensable Book for Town Planners, Architects and Students, ed. Association for Planning and Regional Reconstruction (London: Architectural Press, 1950), 561; Scarlett, "The Application of Air 
as early as World War I, while oblique aerial shots of urban vistas began to illustrate professional magazines during the interwar period. ${ }^{50}$ For example, aerial photographs, mostly obliques, appeared prominently in urban development campaigns by town administrations projecting attractive cities of the future as "place promotion." ${ }^{51}$ Clearly, aerial photographs served to create a new and modern visual representation of cities.

As publications from the period show, architects and planners appreciated aerial photography's ability to contain a vast amount of very detailed information in one (composite) image, a complexity that complemented the growing comprehensive approach toward town planning. ${ }^{52}$ Nevertheless, professionals also began cautioning that the interpretation of the information presented through aerials (especially verticals) demanded professional training and that planners should not lose sight of how projects would affect realities on the ground..$^{53}$ As surveying gained importance in the development of complex large-scale and increasingly systematic approaches to urban planning, aerial photographic surveys became established as the central tool. ${ }^{54}$ By the early 1950 s, aerial photography had become firmly integrated into British town planning curricula. ${ }^{55}$

Aerial photography's success among urban planners, however, was not exclusively rational. Advertisements by the company Hunting Aerosurveys toward the end of World War II demonstrate the enormous and almost supernatural potential that was attributed to aerial surveys. As the market was preparing to shift from a military to a civilian economy, the advertisements adopted the promotional strategy of ascribing a godlike ability of vision to aerial photography in order to sell the company's services to new customers.

Photography to Architecture and Town Planning," 319; see also Dyce, "Canada between the Photograph and the Map," 78.

50 Hinchcliffe, “'The Synoptic View”' 138.

${ }^{51}$ Peter J. Larkham and Keith D. Lilley, "Plans, Planners and City Images: Place Promotion and Civic Boosterism in British Reconstruction Planning," Urban History 30, no. 2 (2003); Peter Larkham and Keith Lilley, "Exhibiting the City: Planning Ideas and Public Involvement in Wartime and Early Post-War Britain," Town Planning Review 83, no. 6 (2012); see also Peter J. Larkham, "Selling the Future City: Images in UK Post-War Reconstruction Plans," in Whyte, Man-Made Future.

52 Whittle, “The Use of Air Photographs," 561.

${ }_{53}$ Following architect Frank Scarlett's presentation on the application of air photography to architecture and town planning at the RIBA Architectural Science Board in 1946, Max Lock raised the question of keeping street-view reality in mind when using aerial planning technologies. See Scarlett, "The Application of Air Photography to Architecture and Town Planning," 322. Hinchliffe has discussed Scarlett's presentation in great detail; see Hinchcliffe, “The Synoptic View."

${ }^{54}$ On the importance of surveying in interwar and wartime urban planning in Britain, see Michiel Dehaene, "Surveying and Comprehensive Planning: The 'Co-Ordination of Knowledge' in the Wartime Plans of Patrick Abercrombie and Max Lock," in Whyte, Man-Made Future.

${ }_{55}$ See the chapter "The Use of Air Photographs" in the Town and Country Planning Textbook: An Indispensable Book for Town Planners, Architects and Students (1950), which served as the official study material for the examination of the Town Planning Institute; on this, see also Whittle, "The Use of Air Photographs." Aerial photography was also taught in US curricula, where it was described as an aid for town planning, as this book taught at Harvard University demonstrates: Branch, Jr., Aerial Photography in Urban Planning and Research. 
3.5 "Town Planning" advertisement published by Hunting Aerosurveys in June 1944 in Flight magazine.

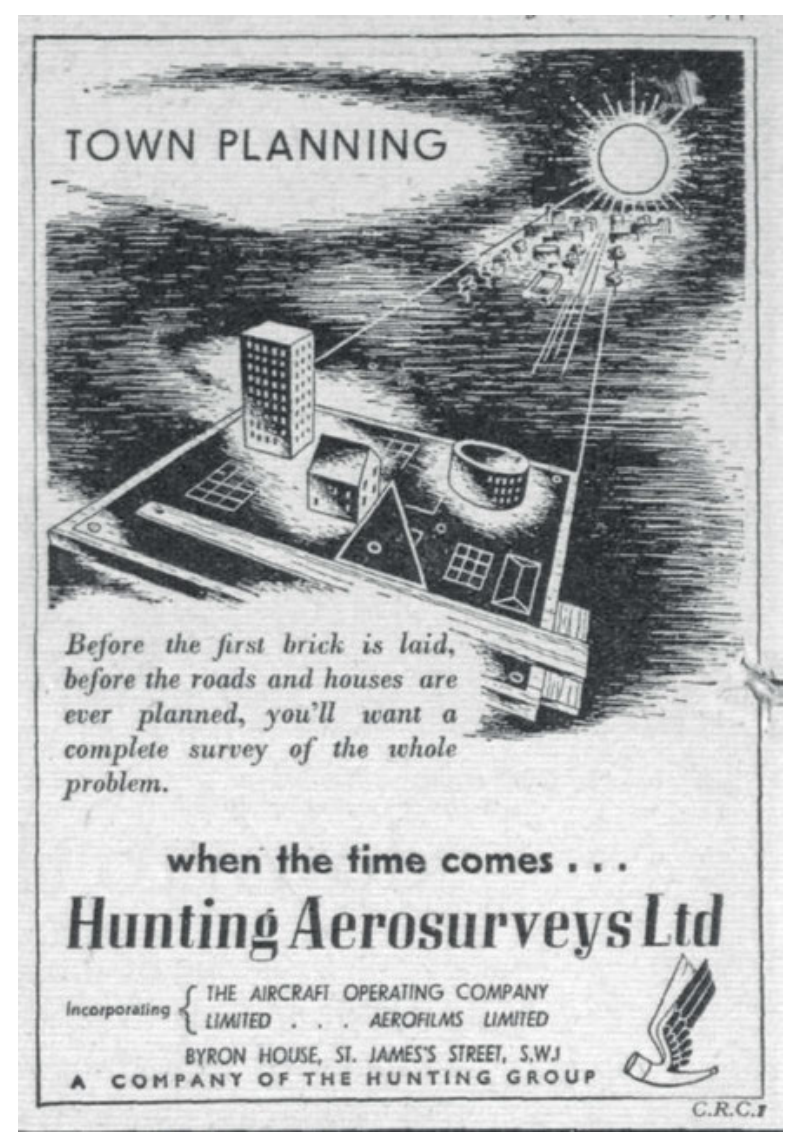

Advertisements placed in Flight by Hunting Aerosurveys and Aerofilms indicate that their main target was the market of urban planning.

Hunting Aerosurveys' first such advertisement appeared in Flight in June 1944 and illuminates the way in which they affectively promoted their services (fig. 3.5). The graphic illustration shows the sun shining brightly in the background, its rays of light reaching a settlement in the far distance and extending toward a drawing board with models of various building types in the foreground of the image. A short text promotes the commissioning of an (aerial) survey prior to starting any building process; the phrase "when the time comes" alludes to the eventual end of the war. Through the combination of text and illustration, the advert symbolizes aerial surveying as sunlight, simultaneously drawing on photography as a light-sensitive technique and playing with the sun's symbolic implications of vision and godlike power, which connects with the idea of the viewfrom-above as an omniscient perspective. In its composition and its thematic focus on the process of seeing, this illustration resonates with the woodcut Making a Perspective 
Drawing of a Reclining Woman by Albrecht Dürer from the mid-sixteenth century. ${ }^{56}$ This print depicts a man drawing an almost-naked woman through a grid window that enables him to see the scene in perspective. Dürer brilliantly encapsulates the seduction that the power to see triggers in humans (symbolized by male-female attraction), especially technically enhanced modes of seeing-just like aerial photography.

After the end of the war, a new series of company adverts declared that "The time has come for Hunting Aerosurveys" (figs. 3.6, 3.7). With the slogan "Let's have a look at the problem," the company addressed their potential civil customers in a jovial tone..$^{57}$ In both adverts shown here, a winged eye-possibly understood as a symbol of godlike vision-hovers over the clipping of an aerial view. ${ }^{58}$ Wherever the eye's cone of light touches the aerial photo, graphic illustrations of well-planned, future townscapes are revealed. The aerial views show either open land (new suburban development) or destroyed cities (rebuilding), the two aspects that dominated postwar town planning in Britain. The landscapes are thereby portrayed as being in dire need of planning. Aerial surveying is hyperbolized as the magic technique of visualizing and, by extension, solving urban problems best.

Aerial photography's magic drew on its (exaggeratedly) ascribed ability to uncover the hidden potentials of landscapes and spaces; in the adverts these were promising new planning and building possibilities in times of a severe postwar housing shortage. This echoed the way in which aerial photography was promoted by oil companies, who encapsulated the god trick with conviction: "A good aerial photograph is a real treasurechest of information and may, within certain limits, be regarded as an absolutely complete record of anything and everything present and visible on the surface of the earth." 59 The fascination with the aerial view was twofold: the seductiveness of the omniscient vision inherent in especially vertical aerials experienced by the viewer and the captivation with the potential or even the promise of altering this landscape. For oil companies it is the tapping of petroleum reservoirs, for archaeologists it is the discovery of ruins and material remains, and for urban planners it is the transformation of space. The aerial vision (in its double meaning of sight and imagination) allows one to look past what is there in favor of imagining what else could be there; in this sense it is not an innocent documentary viewing.

\footnotetext{
${ }^{56}$ Dürer's famous woodcut "Der Zeichner des liegenden Weibes" ("Making a Perspective Drawing of a Reclining Woman") was included in his treaty Underweysung der Messung mit dem Zirckel und Richtscheyt (The Painter's Manual), first published in 1525, and was also reprinted independently.

${ }_{57}$ Hunting Aerosurveys' advertisements appeared in Flight, October 18, 1945, 26 (rebuilding) and Flight, December 6, 1945, 30 (town planning).

${ }_{58}$ The winged human eye also features Leon Battista Alberti's emblem. Scholars have offered various interpretations of this, for example that it symbolizes a father-like or god-like vision. See Laurie Schneider, "Leon Battista Alberti: Some Biographical Implications of the Winged Eye," The Art Bulletin 72, no. 2 (1990).

${ }_{59}$ Krebs, "The Application of Aerial Geology and Aero-Photogrammetry in Petroleum Exploration," 55.
} 


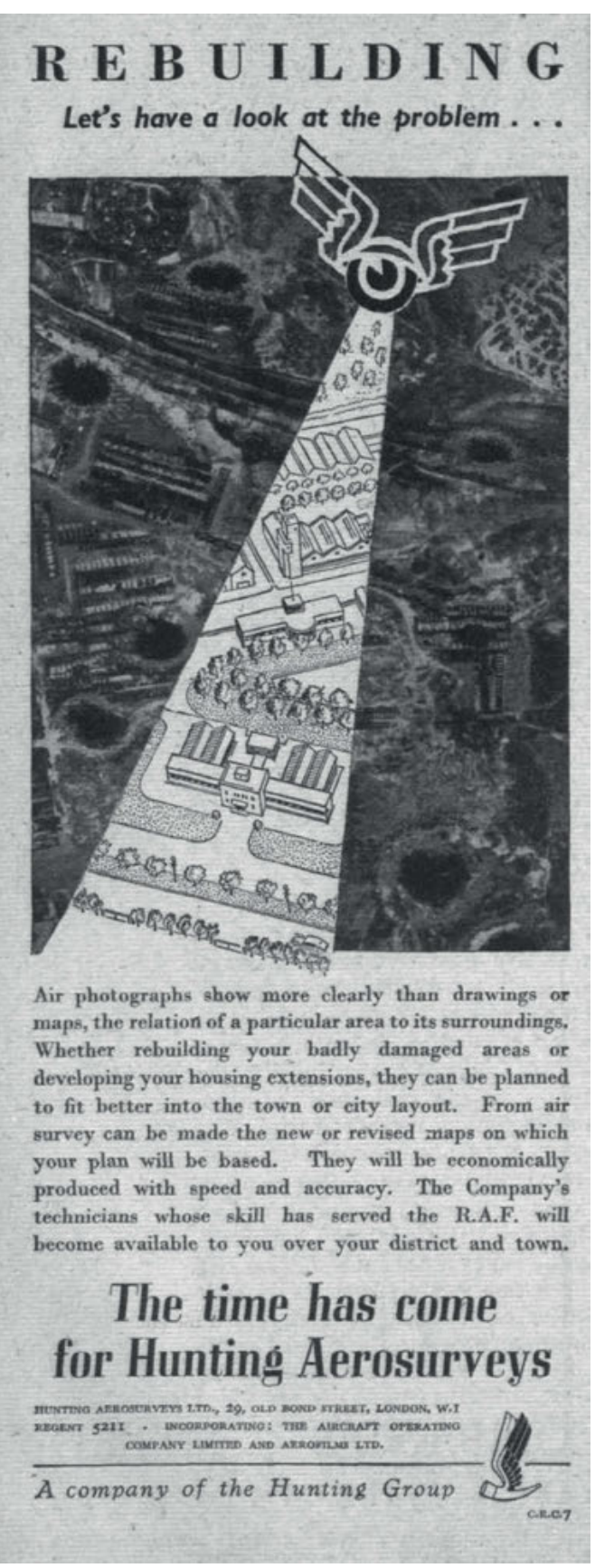

3.6 "Rebuilding" advertisement published by Hunting Aerosurveys in October 1945 in Flight magazine.

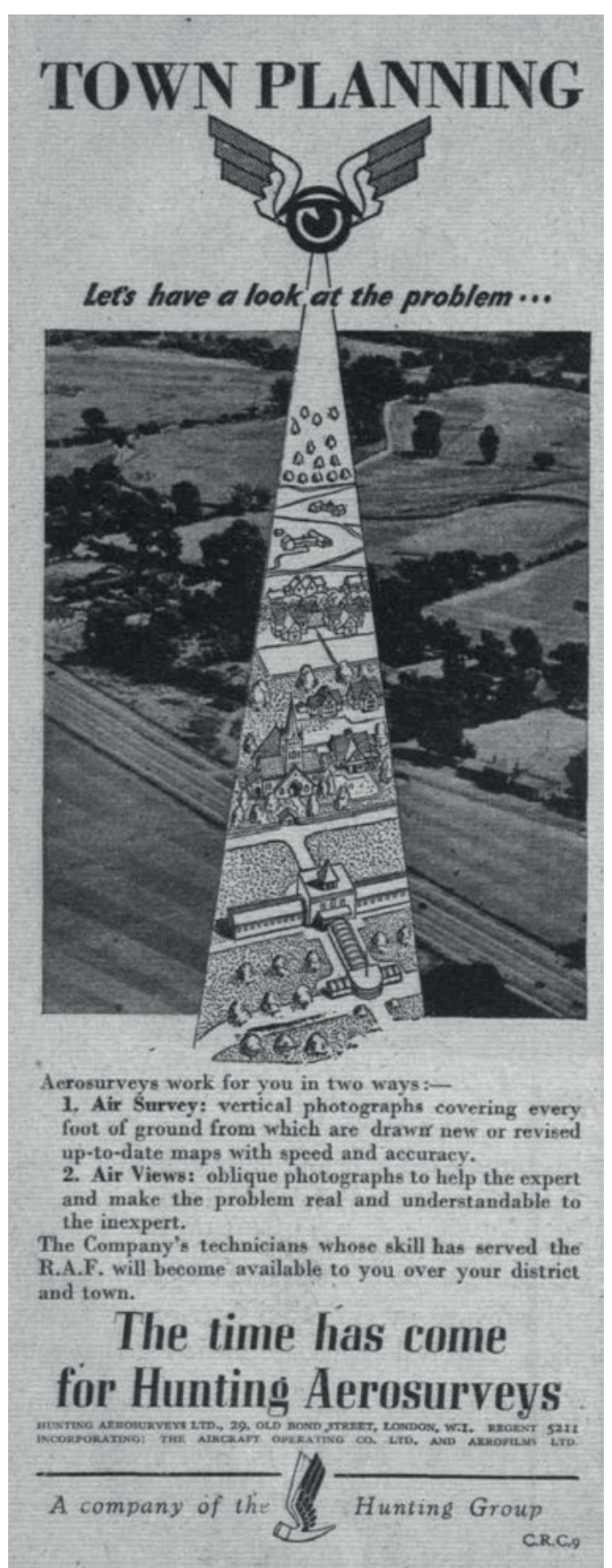

3.7 "Town Planning" advertisement published by Hunting Aerosurveys in December 1945 in Flight magazine. 
MSM's aerial-affirmative approach resonated with commercial advertisements such as those by Hunting Aerosurveys. It also aligned with Anglo-American professional publications that readily embraced the potential of aerial photography to benefit town planning and justified it for remote (meaning little-known by the West) countries in particular. For example, American educator and urban planner Melville C. Branch claimed in 1948:

\begin{abstract}
In the type of urban research which seeks to explore the structural form and various characteristics of diverse towns and cities, air photos can provide that composite view which it is not practicable to obtain by direct visit or by an accumulation of material. When but little data are available concerning places in more out-of-the-way parts of the world, aerial photographs may serve as well for specific information or as the sole or most practical basis for the construction of a descriptive map or plan of the locality. ${ }^{60}$
\end{abstract}

For the three town planners, Kuwait was exactly such an "out-of-the-way" place that consequently required aerial surveying. As Peter W. Macfarlane's stated in one article: "Preparing a plan for such an area presented special problems. The town had never been mapped and the first step was an aerial survey ... from which a plan to a scale of 1:200 was prepared, together with mosaics and oblique photographs of points of importance." 61 The aerial survey not only provided factual information and a "mapping" of the territory-the photomosaic also became engraved into the master plan as a pictorial template and as specific visual-based knowledge.

\title{
The 1952 Master Plan's Aerial Vision of Kuwait
}

The 1952 Master Plan by Minoprio, Spencely, and Macfarlane (fig. 3.8) predominantly focuses on the same section of the Kuwaiti territory as the photomosaic (see fig. 3.3): ${ }^{62}$ the town of Kuwait on the southern shore of Kuwait Bay and the bordering desert extending southwestward. It does, however, incorporate a substantially larger area than the photomosaic, thereby including more land to the south and the second eastern spit of Salmiya. The drawing is inscribed "A Development Plan for His Highness Shaikh Abdulla As Salim As Subah C.I.E." and "Kuwait." It thus establishes a visual and semantic quid pro quo: the development of Kuwait (the town) denotes the development of Kuwait (the country). Historically, the differentiation of the name "Kuwait" as two different topographical entities-the walled-off premises of Kuwait Town or madinat al-Kuwayt and the territorial unit of Kuwait as a whole, which later became the nation-state

\footnotetext{
${ }^{60}$ Branch, Jr., Aerial Photography in Urban Planning and Research, 9.

${ }^{61}$ Macfarlane, "Planning an Arab Town," 112.

${ }^{62}$ The term "master plan" describes a single plan or a set of plans visualizing a comprehensive urban development concept. It can be understood as the macro-plan of an urban planning project aimed at combining all the major planned strategies, for example housing, traffic, and street layout.
} 


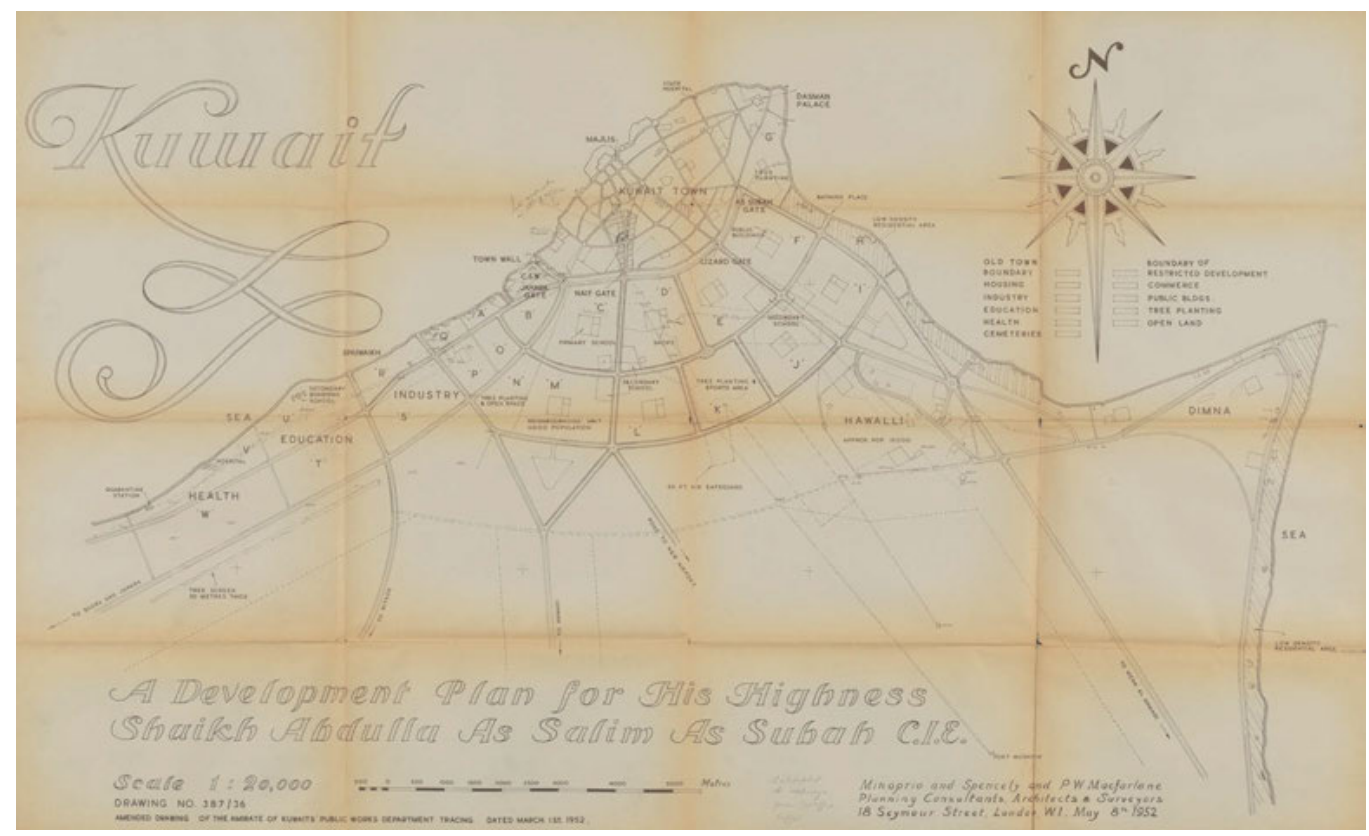

3.8 Development plan by Antonio Minoprio, Hugh Spencely, and Peter W. Macfarlane prepared in $1951 / 1952$ as an urban planning blueprint of a new, modern Kuwait City.

Kuwait-followed the Uqair Convention in 1922 that negotiated the division of land between Saudi Arabia and Kuwait. The idea of Kuwait as a city-state and of modern Kuwait City as its flagship and signboard, that is, as the material, spatial, and visual representation of the country, is key to the master plan.

Based on a scale of 1:20,000 (a little larger than the photomosaic), the plan presents the overall structure and major aspects of the suggested development. ${ }^{63}$ Given the color key in the upper right corner, the plan was originally most likely in color or used hatched patterns. Unfortunately, this rare archival copy preserved in The Postal Museum in London remains mostly blank. Also, the black-and-white illustrations of the master plan usually reproduced in primary and secondary literature show limited legibility; nevertheless, the key information is clearly visible. ${ }^{64}$ Two basic techniques reorganize

${ }_{63}$ The following description is mainly based on the development plan, the document "Plan for the Town of Kuwait" (1951), and a 1954 article written by Macfarlane. See Minoprio, Spencely, and P. W. Macfarlane, "Plan for the Town of Kuwait: Report to His Highness Shaikh Abdullah Assalim Assubah, C.I.E., the Amir of Kuwait," November 1951, Center for Research and Studies on Kuwait; Macfarlane, "Planning an Arab Town," 112-13.

${ }^{64}$ To my knowledge the only color version of the master plan in print currently available was published as part of a small publication by the Kuwait Municipality in 1980. It provides information on the area outside 
the space: first, the area is zoned functionally, with land identified for housing, industry, education, health, cemeteries, commerce, public buildings, tree planting, and open land; second, the road network-described as "boundaries"-is the crucial spatial organizer connecting or separating the functional zones and defining future (motorized) mobility. Using zones and road networks, the plan does not differentiate between already built-up land and "empty" desert. Instead, the projected urban expansion creates a homogenous space that spills across the historical urban demarcation of the town wall with ease.

Nevertheless, the zones and the new street network still differentiate qualitatively between the areas inside and outside the 1920 town wall. The projected thoroughfares within the perimeter of the "old town" are smaller and more irregular, while the area outside is organized by an expanding grid of wide radial and semicircular roads that compartmentalize zones of similar shape and size into "neighborhood units." While commercial and administrative zones are concentrated in the old town, the new residential areas are almost exclusively located beyond the town wall, systematically structured by the grid road system like quilted patches of habitat. Each block, called a "neighborhood unit," contains a multifunctional central area surrounded by private housing. ${ }^{65}$ More blocks stretch along the coast to the spit of Salmiya (here still called Dimna) to the east. In addition, the zones for industry, education, and health are positioned along the shore to the west of Jahra Gate. Only a few buildings and localities are indicated by name, presumably underlining their importance, among them the state hospital, Seif Palace (here called Majlis), Dasman Palace, and Shuwaikh Secondary School. Once again, the information provided does not reflect the fact that some institutions already exist while some are merely projected.

Overall, the master plan proposed nothing less than turning Kuwait City inside out, as it were, by driving the entire population from inside the wall to outside of it. The honeycombed, walled-off town was substituted by clusters of suburban neighborhoods separated by distances that required motorization. In many ways, the vision of the future city of Kuwait paid tribute to a way of living saturated with petroleum and therefore resonates with Stefanie LeMenager's analysis of Los Angeles' urban transformation in the 1930s and 1940s as a manifestation of petroleum culture. ${ }^{66}$ At the core of these processes was the creation of urban space that facilitates motorization, suburbanization,

the old town but-given the print's small size-only does so rudimentarily. See Rashid Al-Rashid, Planning and Urban Development in Kuwait (Kuwait: Kuwait Municipality, 1980), 27.

65 The concept of the neighborhood unit was first developed by Clarence Perry in the Regional Survey of New York and its Environs in the 1920s, see Clarence Arthur Perry, The Neighborhood Unit: Neighborhood and Community Planning; Regional Plan of New York and its Environs (New York: Regional Plan Association, 1929). The concept became increasingly relevant for British urban planning in the 1940s, and is seen for example in Patrick Abercrombie's The County of London Plan (1943); see Michiel Dehaene, "Surveying and Comprehensive Planning: The 'Co-Ordination of Knowledge' in the Wartime Plans of Patrick Abercrombie and Max Lock," in Whyte, Man-Made Future, 45.

${ }^{66}$ LeMenager, Living Oil, chapter 2, The Aesthetics of Petroleum. 
and, subsequently, the distanced consumption of landscape as vistas in a drive-by or even fly-over mode, as characteristic of petro-modernity.

Asphalted roads came to figure as prominent signifiers of such a transformation. For instance, $a l-$ 'Arabì $^{2}$ an illustrated Arab-language social and cultural magazine that was published in Kuwait and that was widely distribution across the MENA region, brought frequent updates on the road system in Kuwait when reporting on the country. In October 1959, the magazine highlighted the ongoing efforts to create 112 kilometers of smooth paved surface that would allow motorized travel at a speed of 120 kilometers an hour along "the first paved road linking Kuwait with the outside," which is today Highway 80 leading from Kuwait City to the northern border, and eventually Basra. ${ }^{67}$ Such reports indicate the symbolic importance attributed to the development of (urban) space through roads that was of public interest. The urban planning policies introduced in Kuwait in the early 1950s resonated in the subsequent master planning of other Gulf cities and no matter how iridescently appealing they seemed then, Assaf and Montagne note in view of today's Gulf cities: “These policies have resulted in comparable landscapes: the urban morphology of Gulf cities today can be characterized by a scattered and discontinuous development where cars are the dominant mode of mobility." ${ }^{6}$

Despite these substantial construction works and changes, "old" Kuwait town remained indirectly visible exactly because of the new road system: the first semicircular ring road substituted the third town wall after it was demolished in 1957, thereby imprinting the outline of the (pre-oil) urban core on the master plan. As the consecutive ring roads were modeled on the first ring road (the former town wall), this pre-oil shape came to resemble a kind of halo in the subsequent urban expansion, a halo that the photomosaic had first brought to light. Yet, in the depiction of this urban vision (the 1952 Master Plan), the almond-shaped pre-oil urban form of the former town of Kuwait had become a mere placeholder for the depopulated new administrative and commercial city center. Conceiving of the pre-oil town as a mere shape or container was the result of seeing Kuwait through the photomosaic from above. However, this was not the only way in which the photomosaic resonated within the master plan. The photography also seemed to shine through the master plan as if it were made of tracing paper.

The 1952 Master Plan acknowledges the town of Kuwait as the epicenter of (national) urban growth and its almond-shaped urban form as its formal nucleus. From this core, various lines and delineated patches symbolizing "development" spread along the entirety of the coastline framed in the plan. This linear (originally colored or

\footnotetext{
67 "Al-Kuwayt yatațala'u ilā l-mustaqbal fī sabīl ghadd 'afḍal [Kuwait Is Looking Forward to the Future on the Road to a Better Tomorrow]," al-'Arabī, no. 11 (October 1959): 114. The same year, the magazine announced, "A million meters of roads are being paved yearly." "al-'Imāra bi-l-Kuwayt [Architecture in Kuwait]," al-'Arabī, no. 13 (December 1959): 62, 70.

${ }^{68}$ Laure Assaf and Clémence Montagne, "Urban Images and Imaginaries: Gulf Cities through Their Representations," Arabian Humanities, no. 11 (2019): 6, https://doi.org/10.4000/cy.4137.
} 


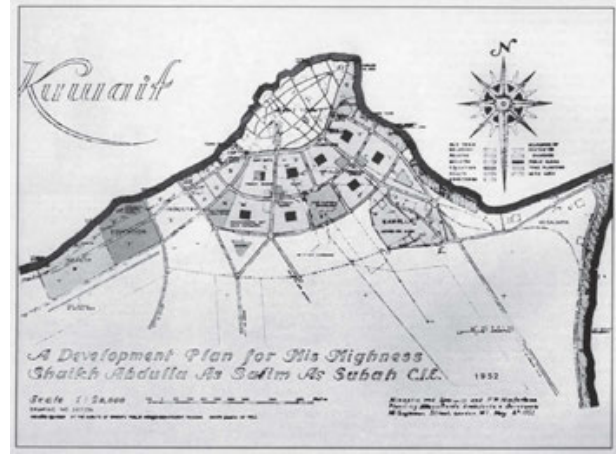

3.9 The development plan as reprinted in Gardiner's Kuwait: The Making of a City.

hatched) texture extends from the core and fans out into single lines (roads). A slightly more amended version of the 1952 Master Plan was subsequently reprinted in Stephen Gardiner's influential publication Kuwait: The Making of a City (1983) and it is here that the relationship between aerial and plan become most visible (fig. 3.9). The starkest contrast in this drawing is provided by the thick dark line that outlines the coastal formation along the two spits but lies beyond the land formation. The stark black-andwhite contrast between the sea and the land mirrors the way in which sea and land are visualized in the photomosaic. Like in the composite photo, Kuwait's land mass rises against the darker undefined frame of the sea. As a result, the spitted shape with an almond-shaped nucleus protrudes from the image. This distinctive shape emerges as an independent form that comes to signify Kuwait (City) not only in the master plan drawing but also in the composite photo. Here, it is evident how much the aerial view has penetrated the planner's visual conception of Kuwait, how much the fossil-fueled, technologically enabled vision of aerial photography has infused the conventions of depicting new Kuwait City. Moreover, in comparison with the photomosaic, the white background of the drawing carrying the wind rose and the calligraphic writing "Kuwait" can be identified as another layer of the image, a layer that is superimposed onto the black area (the sea in the aerial photo), which has been reduced to a thick black line. In this future urbanized image of Kuwait, the sea has become a mere trace on paper, and a backdrop to the sensation of driving-by.

Harking back to the photogrammetric use of aerials, the relationship between the photomosaic and the plan could possibly be similar to that of the aerial survey and the resulting topographic map. Yet, without a grid, topographic details, and the exact geographic localization of such new urban features as neighborhood units, the first master plan cannot function as a topographic map, as a rational device of localization. Instead, it is the drawing of an urban vision that imitates some of the features of a map (northing, wind rose, verticality, color key). It also reflects the selective nature of maps, freely presenting some urban and geographical details while dismissing others, such as the differentiation between the existing built environment and unbuilt land. In this sense 
the first master plan depicts (new) Kuwait City not cartographically but as a pictorial representation of an urban utopia.

Aerial photography allows (urban) landscapes to be translated into images through the use of familiar photographic language. Characteristic of the use of aerial photography in urban planning is that it represents space as accessible, thereby allowing a future or utopian urban form to be imagined, conceived, and visually inscribed into these images of landscapes. This urban planning approach relies on the aerial view, especially the vertical view, to suggest that through aerial photography omniscient vision is possible and that the power to see creates the power to alter landscapes. Inscribed in both the master plan and the aerial photograph is the fundamental belief in landscape as a resource, a belief that is typical of development discourse and even embodied in the term "development plan" itself. The omniscient vertical view has made aerial photography "an increasingly privileged instrument of the double desire of planners - utopian and projective." ${ }^{69}$ These are the seductive attributes that Hunting Aerosurveys readily recognized and promoted in their advertisements, and that clearly also shaped the urban planning approach to Kuwait City. Subjected to this view from above, new Kuwait City in the vision of the 1952 Master Plan became a free-floating form envisioned on the drawing board in remote London: it could have been anywhere and nowhere.

Taking the interpretation one step further, both images can be understood as establishing a continental or onshore image of Kuwait. The black-and-white contrast and the subsequent demarcation of spaces ultimately favors the land, severing it from the sea, which had been reduced to a mere thick black line. Hence, the respective technologies like aerial surveying, mapping, and planning also function as frontier technologies. ${ }^{70}$ This is interesting insofar as the pre-oil history of Kuwait depended on the town's coastal location and maritime economy. These new visual representations forge a break from aligning Kuwait's urban identity with a connecting and nurturing sea; instead, they establish a Kuwaiti identity that is exclusively landbound. In many ways this reorientation is indicative of a socioeconomic and political shift from a society steered by a seafaring merchant class to a ruling family that is the main receiver of oil revenues; the onshore fixation of the oil-extracting economy in Kuwait may also play a part in this change of perception.

In the case of Kuwait, petro-modernity implied turning space into images-yet the resulting disembodied images also influenced the formation of Kuwait's urban space in

\footnotetext{
${ }^{69}$ Anthony Vidler, "Photourbanism: Planning the City from Above and from Below," in Bridge; Watson, The New Blackwell Companion to the City, 656.

${ }^{70}$ On frontier technologies in this context, see for instance Marionne Cronin, "Northern Visions: Aerial Surveying and the Canadian Mining Industry, 1919-1928," Technology and Culture 48, no. 2 (2007). Nelida Fuccaro also emphasized the concept of frontier urbanism for understanding the urban history of the Gulf region. See Nelida Fuccaro, "Middle Eastern Oil Towns as Petro-Histories," paper presented at the conference “The Global Petroleumscape," Technical University Delft, May 18, 2017.
} 
return. In Kuwait Transformed, Farah Al-Nakib has analyzed how the implementation of the first master plan resulted in a new urban environment on the ground characterized by functional zones, neighborhood units, and road networks. Al-Nakib argues that the 1950s urban overhaul neglected and subsequently impaired the social coherence and interaction of people living in Kuwait, eventually leading to a "de-urbanization of society" today. ${ }^{71}$ Viewing Kuwait from above, as projected in the photomosaic and the development plan, had already emptied the urban space of bodies, established movements, and familiar social interaction. The more such images infused Kuwait's urban visual culture, the more this perception became normalized and aligned with the changing urban reality on the ground.

The 1951 photomosaic and the 1952 Master Plan set precedents for perceiving and picturing Kuwait City from above (in the field of urban planning). Looking at the image-world emerging in the 1950s in Kuwait, the aerial view began to manifest as a dominant depiction of Kuwait City across a range of different media and outlets that worked to position Kuwait City firmly in the context of petro-modernity to lasting-yet ambiguous-effect.

\subsection{Representational Ambiguities}

In the 1950s, Kuwait was on everyone's lips. Articles in The Times, Fortune, National Geographic, and many others reported on Kuwait's development, its emerging cityscape, its civic transformation, its newfound wealth, and of course its oil industry. Dynamic postwar economies around the globe engaged in petro-modernity and shared a feverish interest in places where oil was produced. All reports about Kuwait talked about oil in one way or another and many were illustrated with aerial views of the transforming landscape to showcase Kuwait's story of oil to both local and foreign audiences. Yet it was not just in published images that the view of Kuwait from above proliferated: due to the rise of commercial air travel, this view speedily turned into a personal experience for many.

Kuwait encountered a strong increase in air travel in the postwar period, of which many passengers were involved in the oil business and more generally in the urban transformation of Kuwait. The city-state of Kuwait, surrounded as it was by either desert or the Gulf, became a frequented airport quickly. From 1948 onward, the British Overseas Airways Corporation (BOAC), among several other airlines, started flying to Kuwait every two weeks. ${ }^{72}$ By 1954, BOAC served Kuwait twice a week. ${ }^{73}$ Three years later, Kuwait was

\footnotetext{
71 Al-Nakib, Kuwait Transformed. Al-Nakib's work is informed by the critique of "high modernism" as formulated by James C. Scott, Seeing Like a State: How Certain Schemes to Improve the Human Condition Have Failed (New Haven: Yale University Press, 1998).

72 “Desert Pioneers: Aviation in Kuwait, the Impetus from Oil," Kuwaiti Digest, April 1973, 10.

${ }^{73}$ Macfarlane, "Planning an Arab Town," 110.
} 
fully integrated in the commercial aviation network in the Middle East. ${ }^{74}$ An enlarged transitional airport was built in 1961 and the commission for a new international airport was granted a year later. ${ }^{75}$

Despite the lack of precise figures, it can be safely assumed that, by the late 1950s, many people living and working in Kuwait were no longer traveling by boat or overland but by airplane. The harsh climate conditions during summer along with a new petro-dollar infused wealth readily promoted air travel not only as the fastest and most comfortable means of traveling but also as a lifestyle. Journalist Peter Mansfield, who visited Kuwait in 1958 and 1961, recalls that "with the first rush of affluence in the 1950s every Kuwaiti who could afford it left the country during the savage summer heat. lt seemed to me at the time that Kuwait would in the future be actively deserted during July and August." ${ }^{76}$ In fact, this is the case today. In addition, the significant population of workers and professionals from Europe and the US, but also increasingly from other Arab countries, India, and Pakistan living in Kuwait commuted by airplane. ${ }^{77}$ As flying gradually turned into a mass phenomenon not only in Kuwait but in many countries, air travel was not just about mobility and affluence. It also introduced and eventually familiarized the positionality to view places from high above.

Together with new technologies of vision, fossil-fueled motorization and its unprecedented speed turned built environments into vistas of landscapes in a drive-by or fly-over mode. The resulting distant observer position is evident in Peter Lienhardt's observation when first arriving in Kuwait in 1953: "Reaching a strange place by air is like seeing it on television: the people who live there are just part of the scenery. Perhaps that is what 'international' has come to mean now." ${ }^{78}$ Increasingly, petro-modernity meant experiencing space as image by petroleum-enabled means.

\section{New Shapes in Kuwait's Cartography}

The spatial visualizations of Kuwait that proliferated in articles discussing Kuwait in the mid-twentieth century reified the aerial view not only as reprinted photographs but also in the form of maps. These maps ranged from simplified figures to colorful and elaborate drawings. Many presented little more than the country's name, the national borders, and the location of the capital, and primarily indicated Kuwait's geographical position

\footnotetext{
${ }^{74}$ Keith Williams, "Commercial Aviation in Arab States: The Pattern of Control," Middle East Journal 11, no. 2 (1957): 134-35, table 2.

${ }^{75}$ Saba George Shiber, The Kuwait Urbanization: Being an Urbanistic Case-Study of a Developing Country: Documentation, Analysis, Critique (Kuwait: Kuwait Government Printing Press, 1964), 104; Fabbri, Saragoça, and Camacho, Modern Architecture Kuwait, 154-55.

${ }^{76}$ Mansfield, Kuwait, 125.

77 Williams, "Commercial Aviation in Arab States," 134-36.

${ }^{78}$ Lienhardt, Disorientations: A Society in Flux, 23.
} 


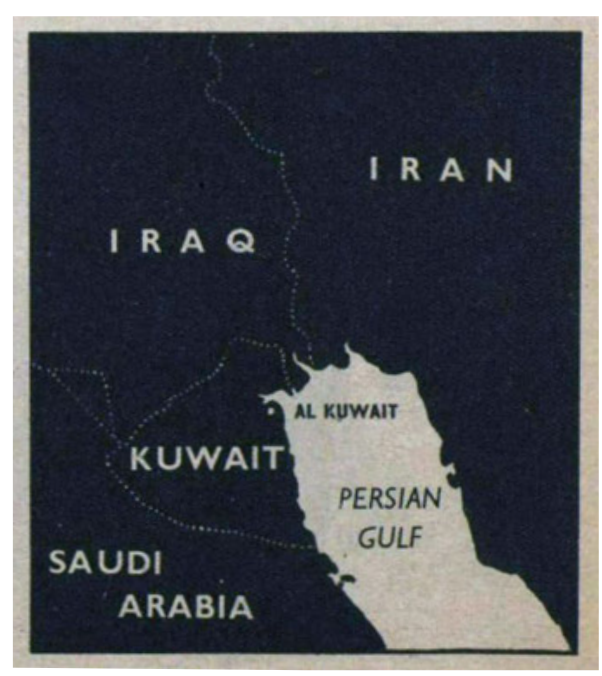

3.10 Simplified map of Kuwait published in July 1946 in Picture Post.

in relation to other countries. Most importantly, however, the cartography of this period had more than the aerial view in common with the aerial photography of May 1951 and the 1952 Master Plan. The new maps proliferated the iconic image of Kuwait City in the form of new emblematic shapes: the almond-like form (modeled on the 1920 town wall) of Kuwait town situated within the wave-shaped spit that is so characteristic of Kuwait's coastline. The emergence of these shapes was tied to the new visualization practices that aerial surveying and urban planning had given way to.

This popularization of depicting Kuwait City through shapes and the aerial view becomes most evident when comparing several such map-like drawings. A map illustration in a 1946 issue of the British magazine Picture Post presents "Al Kuwait" somewhere lost in the blackness of the landmass (fig. 3.10). With the dotted lines indicating the national borders like a string of lights, the illustration seems to resemble a night view of Kuwait, whereby Kuwait City accounts for merely one larger dot. These maps also served to affirm Kuwait's status as a bordered territory, one of the key characteristics of a nation-state (which Kuwait was in the process of becoming).

From mid-1951 onward, Kuwait City has frequently been represented as an almondshaped area that is nested in the refined pointed spit of Kuwait Bay, as a figure in the Illustrated London News demonstrates (fig. 3.11). ${ }^{79}$ The Kuwaiti government gazette also integrated this aerial representation of the almond-shaped town into its original 1953 cover (which has not changed since), thus suggesting the normalization of the aerial

\footnotetext{
79 “The Mysterious Land of Kuwait," Picture Post, July 13, 1946, 14; photographs by N. Tim Gidal; "The World's Largest Single Oilfield: Kuwait and Its Fabulously Rich Ruler," Illustrated London News, June 30, 1951, 1061.
} 


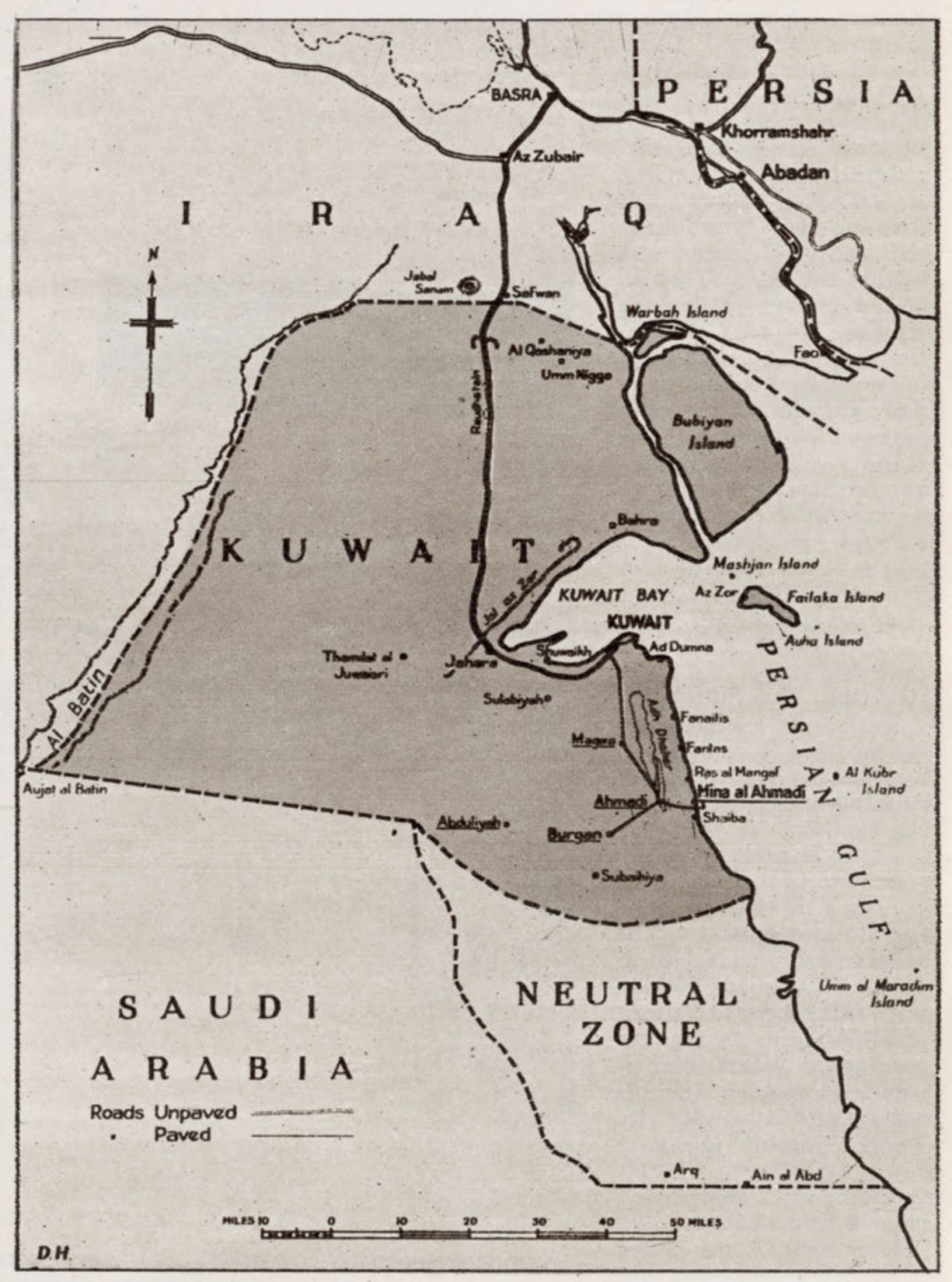

3.11 Map of Kuwait with road network published in June 1951 in the Illustrated London News. 
viewing position and the integration of the view from above into Kuwait's national state-driven imaginary (see fig. 5.2).$^{80}$ Conceiving of Kuwait through/as a map-like icon resonates with Benedict Anderson's description of a "map-as-logo," which he considers a powerful visual vehicle of nation building. ${ }^{81}$ Anderson suggests that, by being reproducible and transferable across media and spaces, such images gain influence by being "instantly recognizable and everywhere visible." 82 Processed through aerial photography and urban planning, the starkly simplified urban form of pre-oil Kuwait became the symbol of the modern oil city. Consequently, although the 1952 Master Plan set out to completely overhaul the existing town based on the aerial survey, the visual representation of this aerial vision fostered not only the preservation but also the popularization of the pre-oil urban form as iconic of New Kuwait City and the country as such. The inherent tension charged the visual representation of Kuwait City with that strongly affective ambiguity that characterizes petro-modernity's iridescence.

While traces of pre-oil Kuwait in the form of iconic shapes rapidly proliferated in all kinds of visual media, throughout the 1950s and 1960s much of what Kuwait's urban fabric had hitherto consisted of was erased according to the dictates of the first master plan. The 1951 aerial survey had produced the access points through which to conceive of landscapes as fit for drastic turnovers. Yet in the case of Kuwait, these aerials were simultaneously used to disguise, circumnavigate, and ignore the dramatic urban changes on the ground.

\section{Kuwait Frozen in the 1951 Oblique Photography}

MSM were among the first to publish the brand-new obliques taken of Kuwait during the aerial survey of May 1951. In contrast to the perpendicular comprehensiveness of the verticals (from which the photomosaic had been produced), these obliques captured the city in parts and from an inclined perspective. MSM's first article, titled "Planning Problems in Kuwait," appeared in The Architect and Building News in July 1951, shortly after MSM's second visit to Kuwait and only two months after the survey; the article was reprinted in Town and Country Planning in September. ${ }^{83}$ Central to the article and its reprint-a status-quo report on Kuwait's oil-induced development and future urban

\footnotetext{
${ }^{80}$ For a detailed analysis of the government gazette see Chapter Five.

${ }^{81}$ Benedict Anderson, Imagined Communities: Reflections on the Origin and Spread of Nationalism, rev. ed. (London: Verso, [1983] 2006), 175.

82 Ibid., 163-64, 170-78, here 175.

${ }^{83}$ While initially all three were named as authors, the September reprint indicates Macfarlane only. Hence, he was presumably the main author in the first place, possible being the writer in the team. Anthony Minoprio, Hugh Spencely, and Peter W. Macfarlane, "Planning Problems of Kuwait," The Architect and Building News 200, no. 4310 (July 1951); Peter W. Macfarlane, "Planning Problems of Kuwait," Town and Country Planning 19, no. 89 (September 1951).
} 


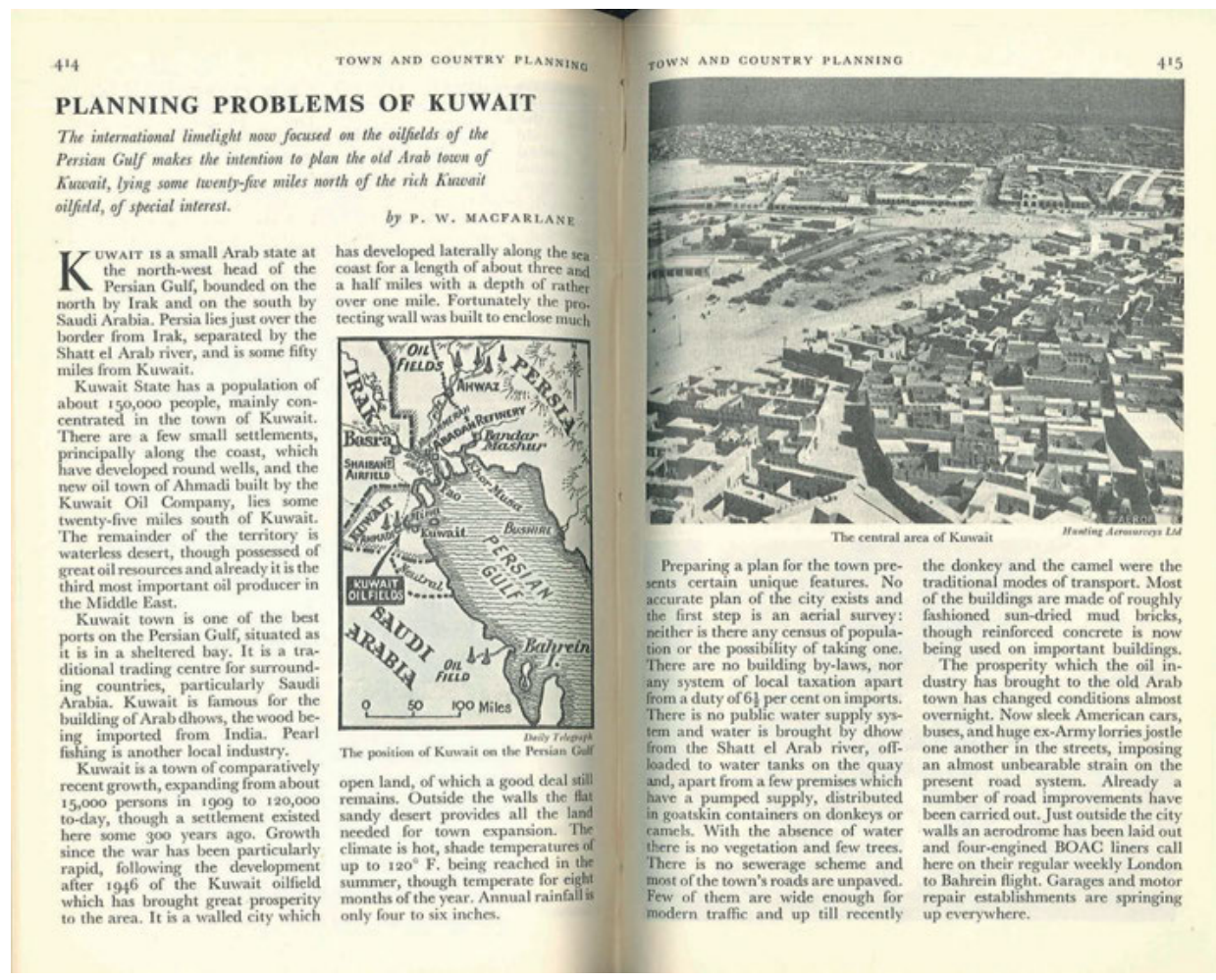

3.12 The Central Area of Kuwait [Safat Square]. Oblique photograph taken in May 1951 by Hunting Aerosurveys/Aerofilms and reproduced in Peter W. Macfarlane's article "Planning Problems of Kuwait" in Town and Country Planning, September 1951.

rebuilding - is an almost identical oblique photograph of Safat Square, the town's center, viewed in the direction of the Persian Gulf (fig. 3.12).$^{84}$ Notably, this oblique-not the photomosaic or another vertical photograph-had been selected to provide a first impression of Kuwait to a wider audience, possibly because of the greater accessibility and pictorial quality attributed to oblique photography compared to verticals.

As one of the large open spaces within the surrounding neighborhoods of honeycombed groups of flat-roofed courtyard houses, Safat Square generally offered a clear point of orientation in Kuwait. At the time the photograph was taken, the open space was crowded with a makeshift market structure and pedestrians and some cars frequented the surrounding unpaved streets. When viewed in light of the "planning problems"

\footnotetext{
${ }^{84}$ Aerofilm is credited in the July issue, but Hunting Aerosurveys is credited in the September issue. In 1951, Aerofilm already belonged to Hunting Aerosurveys but continued under its original name and specialized in oblique photography. This shows that the aerial survey of Kuwait undertaken in May was not only used to take vertical photographs for a photomosaic but also for oblique photos.
} 


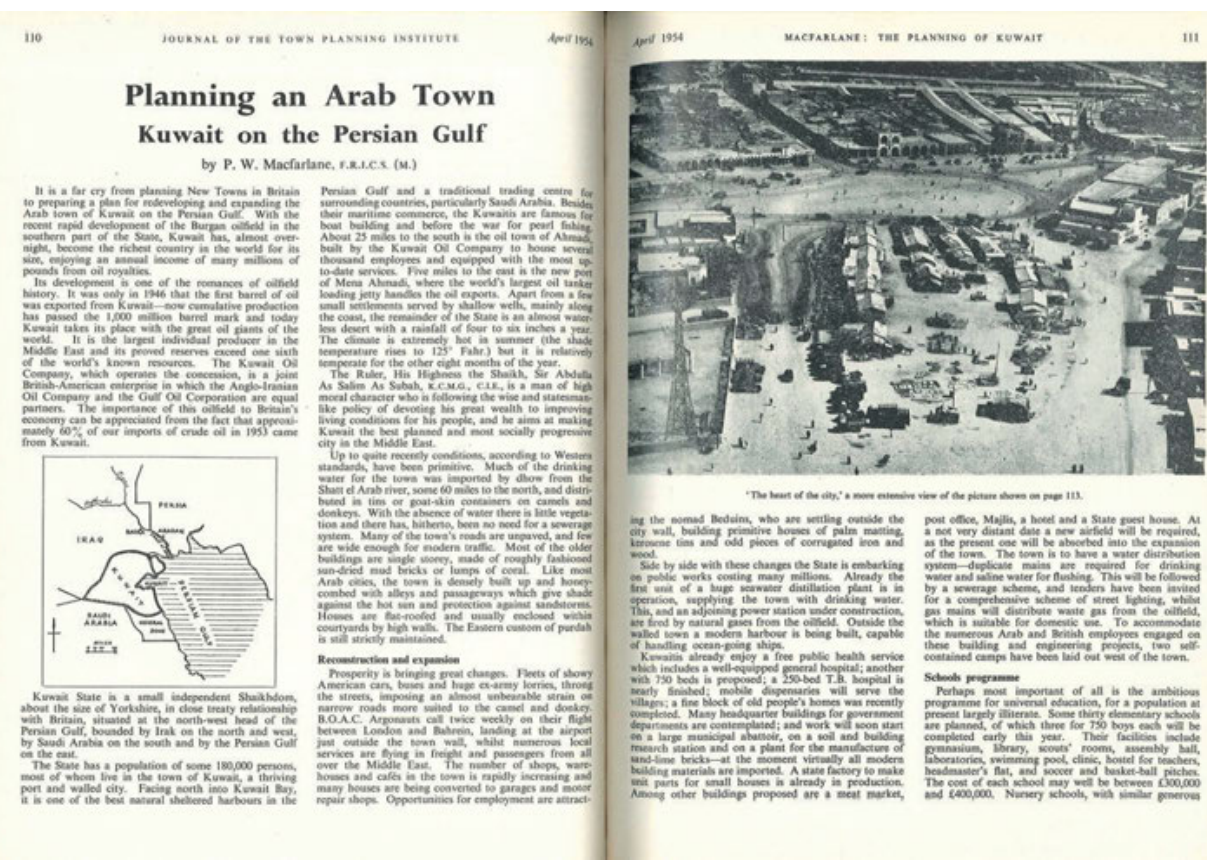

3.13 The Heart of the City [Safat Square]. Oblique photograph taken in May 1951 by Hunting Aerosurveys/Aerofilms and reproduced in Peter W. Macfarlane's article "Planning an Arab Town," in Journal of the Town Planning Institute, April 1954.

referenced in the article's title, the aerial supported the impression of a crowded, disorganized historical urban core that needed reorganization. Evidently this particular oblique was chosen to legitimize the urban planners' agenda overseas, as it justified the process of "rebuilding" according to Western town planning standards.

Three years later, in 1954, Peter W. Macfarlane, one of the town planners, published an article titled "Planning an Arab Town: Kuwait on the Persian Gulf" in the Journal of the Town Planning Institute. ${ }^{85}$ Again, an oblique of Safat Square was featured, this time a close-up (fig. 3.13). ${ }^{86}$ Close comparison reveals that the photo is a variation of the oblique published in the 1951 articles, which proves that MSM continued working with the set of obliques (and verticals) from 1951. Similarly, the magazine Architectural Design featured Kuwait's master plan as part of a special issue on "Architecture in the Middle East" edited

${ }^{85}$ Macfarlane, "Planning an Arab Town," 110-13.

${ }^{86}$ The photo's caption identifies Safat Square as the "heart of the city" and thus references the eponymous 8th CIAM congress (1951), but without reflecting its debates. See Sigfried Giedion, "CIAM 8: The Heart of the City: A Summing Up," Ekistics 52, no. 314/315 (1985). For an historical assessment of the metaphor "heart of the city," see for example Konstanze Sylva Domhardt, The Heart of the City: Die Stadt in den transatlantischen Debatten der CIAM 1933-1951, Architektonisches Wissen (Zurich: GTA Verlag, 2012), 330-48. 
by Raglan Squire in March $1957 .{ }^{87}$ Alongside the master plan and a neighborhood unit scheme a 1951 oblique photograph of the vernacular housing clusters close to the shore was published. Subsequently, not only MSM's understanding of Kuwait but also a larger professional audience's understanding of Kuwait remained, at least visually, limited to this one visual record of May 1951. This was problematic, because what in 1951 was an up-to-date visual document of Kuwait had by 1954 already become a historical record of Kuwait; by this time Kuwait was already undergoing major reconstruction and no longer resembled the images taken in 1951. Macfarlane himself underscored the change in the article. ${ }^{88}$ Within the frame of just three years the aerials had aged dramatically: they now presented an image of Kuwait town that existed only as pictures and memory.

While the oblique in the 1954 article gave readers an impression of Kuwait's initial situation that was limited to the moment of the planners' first visit, the written text itself delivered a well-informed update about ongoing and planned rebuilding. That it included a detailed description of the 1952 Master Plan appears to suggest that MSM's town planning should continue to be read as a remedy to the urban situation as captured in the oblique (as already insinuated in the 1951 article). In combination with the oblique, the textual rendition of the master plan served to position the concept as the ultimate solution for change and development.

While the aerials encapsulated and simultaneously muted the preexisting (built) environment, the master plan unfolded a much stronger symbolic power: it gave at least the impression of being able to change this particular urban space irrespective of actual conditions on the ground. In this logic, the photograph no longer projects a status quo as a prerequisite to action but becomes subjected to photography's trap of conserving time and space in an eternal deadlock. The realistic aesthetic of the oblique photograph disguises the fact that it is basically no longer a sign of modernity, no longer a depiction of the present and projection of the future; rather, it now represents a past that has been arrived at overnight. Elsewhere, urban geographer Matthew Gandy has argued that "urban form can be interpreted as an accumulation of the past viewed through the concerns of the present." ${ }^{89}$ However, in the case of Kuwait City and other petro-modernized cities that were so quick to "overhaul" their recent pasts, their physical urban form was almost too strained to provide for the past. Instead, in these spaces, visual representations such as aerial photographs, maps, and even master plans became images from which to interpret the past-and also to affectively access the past as Chapter Seven discusses. They thereby took the place of memory even for 1960s contemporaries as we will shortly see, which in other cases was tied to such architectural traces as physical ruins.

${ }^{87}$ Charles A. Minoprio, Hugh G. C. Spencely, and Peter W. Macfarlane, "Plan for Kuwait," Architectural Design 27, no. 3, special issue, Architecture in the Middle East, ed. Raglan Squire (March 1957): 75.

${ }^{88}$ Macfarlane, "Planning an Arab Town," 113. By "this country" the author was referring to Britain.

${ }^{89}$ Matthew Gandy, "Landscape and Infrastructure in the Late-Modern Metropolis," in Bridge; Watson, The New Blackwell Companion to the City, 58. 


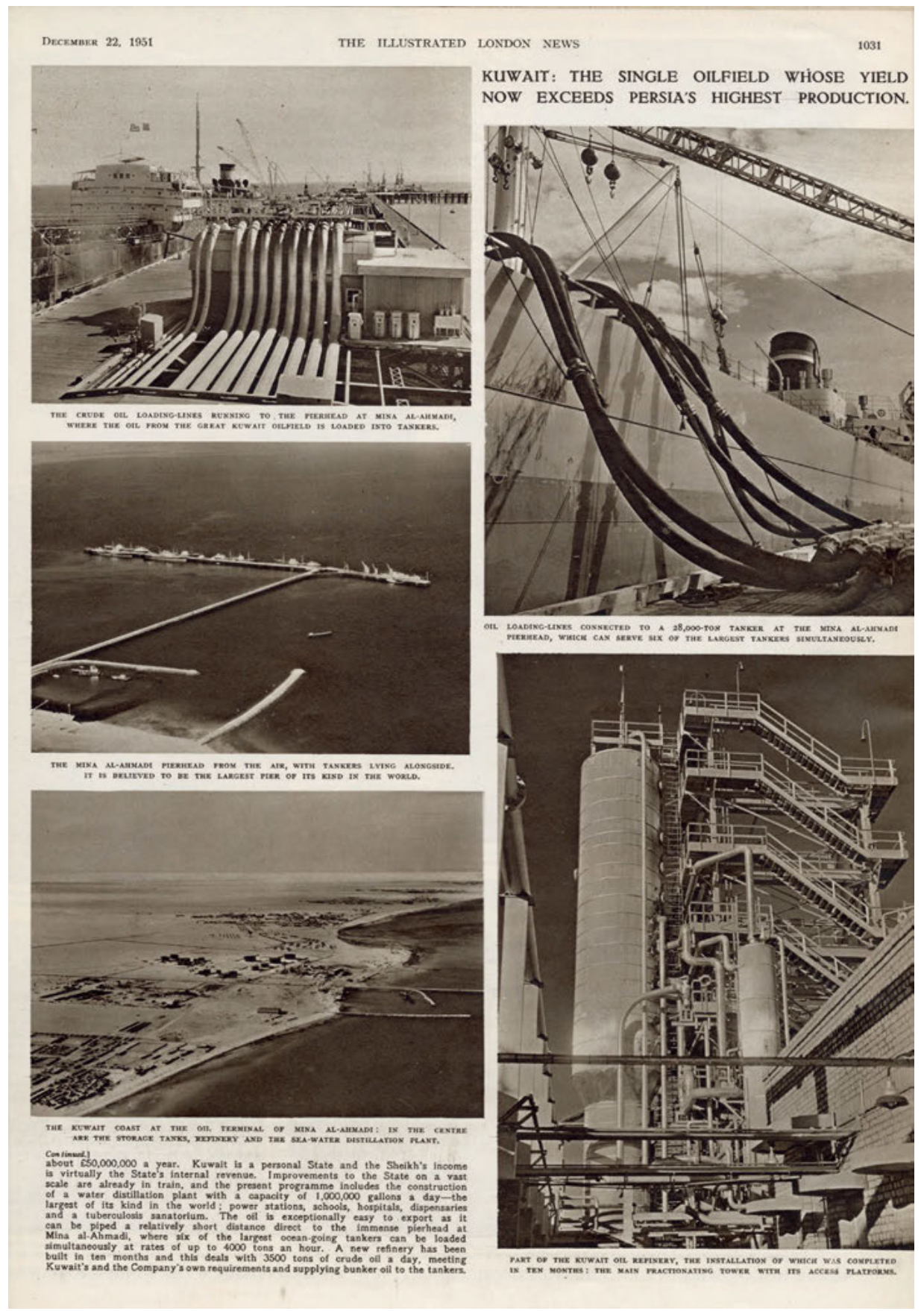

3.14 A picture essay of Kuwait with oblique photos of Kuwait City (from the 1951 aerial survey), of the oil installations, and shipbuilding as published in the Illustrated London News, December 1951. 


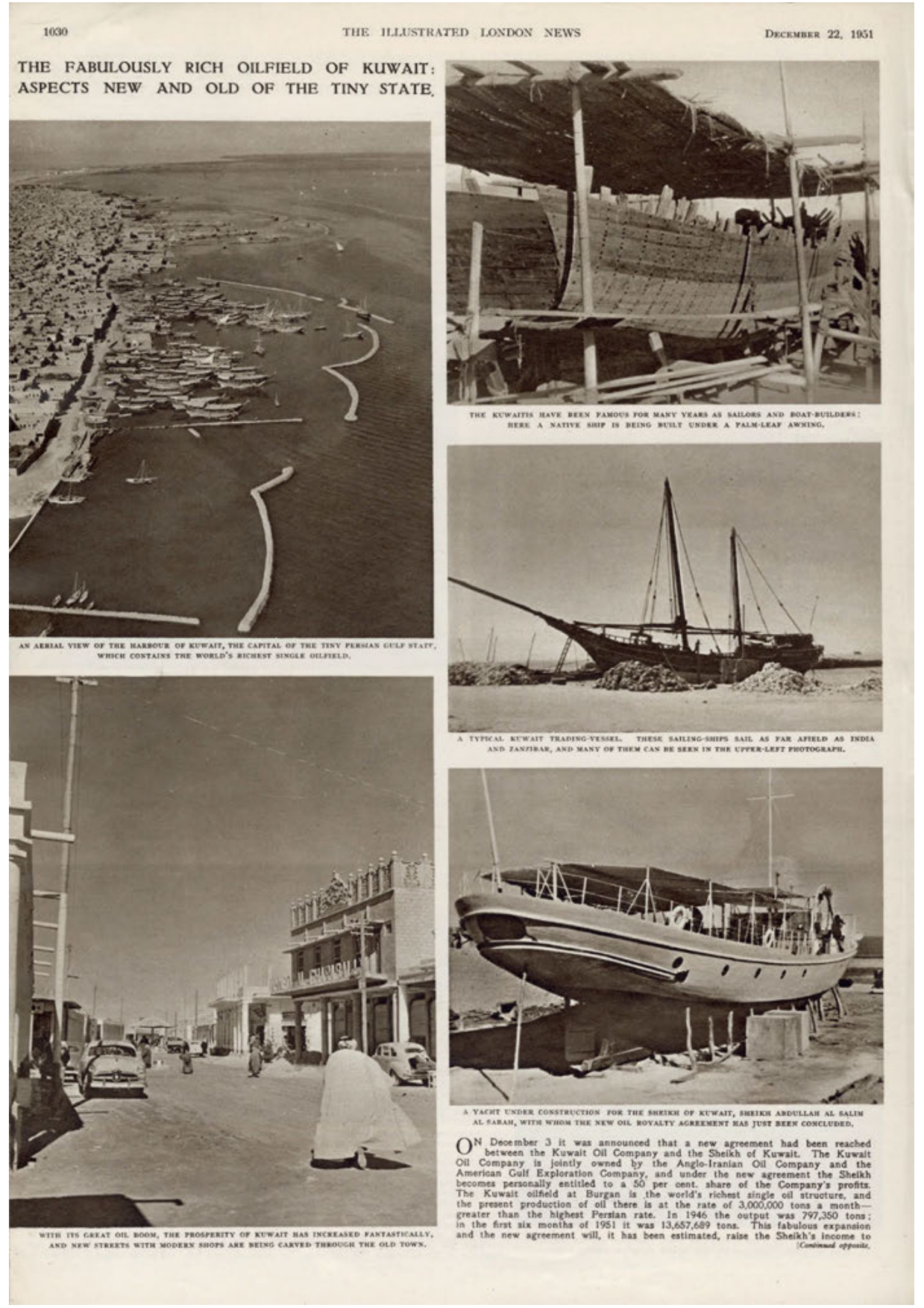


Through the frequent, although not exclusive use of the 1951 obliques that depicted the densely knit (pre-oil) urban fabric in the general press throughout the 1950s, Kuwait's aerial appearance was frozen in this visual status quo; despite the fact that, as one urban planner noted in 1964, "the building boom in Kuwait went berserk during especially the period 1954 to $1962 . " 90$ This impression was amplified by the proliferation of another group of motifs in photographs of Kuwait that showed large and newly-completed building projects-and especially massive and sophisticated-looking oil infrastructure, often as singular structures. These were, for example, pictures of the oil jetty at Mina alAhmadi or a group of oil tanks in the desert, as shown on page 2 of a two-page article on Kuwait in the Illustrated London News of December 1951 (fig. 3.14). ${ }^{91}$ Suddenly, the view from above of the pre-oil town of Kuwait was juxtaposed with these brand-new structures across the pages, even in these articles. This field of tension between old and new also resonated in the different types of ships currently under construction in Kuwait's wharves (see fig. 3.14).

While the sites of petroleum infrastructure and other building projects like schools emerged as organized, controlled, and recently built spaces of utmost productivity, the town of Kuwait became emblematic of an almost nostalgic or at least romantic notion of a dense, white-washed, and flat-roofed Middle Eastern coastal settlement. In such media outlets, the 1951 aerials played a crucial role in constructing the pre-oil town as inadequate, backward, inferior, and outdated, thereby not only fueling but justifying Kuwait's drastic rebuilding throughout the decade in the eyes of their readers. Although Kuwait's urban transformation was also visualized through individual photographs of newly built schools, government buildings, villas, and so on shot from street level, throughout the long 1950s the town-as a comprehensive unit-was frozen in time by means of these oblique photographs. This rapidly changed when a new comprehensive aerial survey was undertaken in October 1960 and the 1951 aerials were suddenly critically compared and reviewed.

\section{Assessing the Urban Transformation in the 1960s}

By the early 1960s the town of Kuwait had transformed into Kuwait City. Its population had tripled and the area of the city had expanded significantly beyond the town wall and become flooded with cars. ${ }^{92}$ Suburbanization, motorization, abundant energy, and water supply, all made possible by oil revenues and fossil energy, had transformed the city lastingly and visibly. The most well-known view of Kuwait had become the aerial view from an airplane as captured by journalist Peter Mansfield in 1961:

\footnotetext{
90 Shiber, The Kuwait Urbanization, 2.

91 "The Fabulously Rich Oilfield of Kuwait."

${ }_{92}$ Al-Arabī called attention to the "twofold expansion of the city in four years," "al-'Imāra bi-l-Kuwayt [Architecture in Kuwait]," 62.
} 
Kuwait City already appeared at night from the air as a huge metropolis, with the lights of the new suburbs stretching for miles into the surrounding desert. Some of the new villas were uncompromisingly garish but their gardens greatly improved the city's appearance. Palms, tamarisks and acacia ... were being planted along the city streets and kept alive at considerable cost. ${ }^{93}$

The 1951 aerial photographs were now undisputedly outdated but far from irrelevant. When the next comprehensive aerial survey was undertaken in October 1960, the 1951 aerials now provided a basis of visual comparison; they became both historical evidence of the existence of the pre-oil town and of the massive overhaul that had taken place. ${ }^{94}$ While the small mud-plastered alleyways and courtyard houses vanished, multistory concrete buildings had begun appearing inside and futuristic detached villas outside the former town wall.

The new 1960 aerials confronted professionals with the fact that Kuwait's de facto urban expansion was already far greater than the template, the 1952 Master Plan, had envisioned just under a decade earlier and thus also revealed the practical limitations of such visualizations. Urban planner Saba Georg Shiber vividly recalled that the (comparative) view from above "came as a surprise to all responsible planning authorities and officials, engineers, and architects" in Kuwait in $1960 .{ }^{95}$ Indeed, Kuwait's urban transformation was well under way, but instead of transitioning smoothly from a preoil coastal town into the neatly delineated shapes, roads, and forms of the master plan, it had gained a different dynamic altogether. In this context, aerials suddenly served to assess Kuwait's development in reverse, which meant that images were used to examine a spatial transformation, which had been based on images in the first place, through which new images were created in return. Evidently Kuwait was fully immersed in the symbolic process of petro-fueled visual representation characteristic of petro-modernity, a mirroring process insinuated by the (self-)reflecting iridescent sheen in the sculpture Alien Technology. How the aerials were discussed as highly ambiguous symbols of Kuwait's petro-modernity is best explored through the lens of Saba Georg Shiber's study of Kuwait's urban transformation: The Kuwait Urbanization: Being an Urbanistic CaseStudy of a Developing Country; Documentation, Analysis, Critique.

Shiber (1923-1968), a Jerusalemite architect, planner, consultant, and writer who held several degrees from Arab and American universities in the field of architecture and planning, published The Kuwait Urbanization in both Arabic and English in June 1964.

\footnotetext{
${ }^{93}$ Mansfield, Kuwait, 43.

${ }_{94}$ Subsequently, updated obliques of Kuwait were also reprinted in the popular press, lifting Kuwait's visual standstill in aerial photography. "One of the Richest Cities in the World, Threatened by Iraqi Claims of Sovereignty: An Aerial View of Kuwait Town which Flourishes on Oil Revenues," Illustrated London News, July 8, 1961, 54-55; "Threatened by Iraq but Supported by the Other Arab Countries: Oil-Rich Kuwait and Its Ruler," Illustrated London News, July 8, 1961, 1.

${ }_{95}$ Saba G. Shiber, "Kuwait: A Case Study," in From Madina to Metropolis: Heritage and Change in the Near Eastern City, ed. L. C. Brown, Princeton Studies on the Near East (Princeton: Darwin, 1973), 183 (italics in the original).
} 
At the time he had been working as an architectural and city planning adviser to several Kuwaiti government institutions such as the Public Works Department, the Development Board, and the Municipality over the past four years. ${ }^{96}$ The publication can be considered the earliest comprehensive, first-hand assessment of the country's urban transformation over the by then past fourteen years and an important primary source of an Arabic debate on modern urban planning. Spread across 644 richly illustrated pages, The Kuwait Urbanization is a scholarly endeavor, history book, photo album, and artistic picture book for which Shiber drew on his professional education and long-standing experience and in which he attempts to settle the score with Kuwait's first master planning.

The mere fact of Shiber's employment marked a shift in urban planning politics in Kuwait and in fact in the Arab world at large, as his persona incorporated what Haraway describes as situated knowledge. Instead of British or American "circulating experts," circulating Arab professionals who worked and lived in Kuwait and eventually Kuwaitis became important players in the field. The nascent vernacular field of Arab urban experts manifested in conferences such as The New Metropolis in the Arab World that took place in Cairo in December $1960 .{ }^{97}$ Shiber, who was a participant, developed a critical position toward Kuwait's development formula in the early 1960s. He was well aware of the necessity to modernize cities and also borrowed from Western theoretical models and techniques of visualization, yet, in contrast to MSM, he emphasized that the town of Kuwait as it had existed at the beginning of the 1950s would have provided an urban form with its own characteristics, good or bad, from which to start. As Aseel Al-Ragam has shown, "his intention was to position the Arab city as a model equal in value to its western counterpart" in order "to make way for a more sensitive design approach based on context" and appreciative of an earlier urban history. ${ }^{98}$

Long before "petro-urbanism" or "oil urbanization" was systematically analyzed and categorized, Shiber already described it as such by identifying oil and the car as the driving forces of Kuwait's rapid urban change and especially growth. Characterized by unprecedented speed, it was, in Shiber's words, "this unique and voracious urbanization

\footnotetext{
96 The Jerusalemite had studied civil engineering at the American University in Beirut (B.A., 1944) and architecture at Cairo University (B.Arch., 1946), before moving to the US where he obtained an M.A. in architecture from MIT in 1947 and an M.A. in city planning from the same university in 1948. Six years later he completed a PhD in City and Regional Planning from Cornell University, apparently as the second Arab candidate in the whole of the US. He then worked in the US, in Lebanon, Syria, Jordan, and Saudi Arabia (for ARAMCO) before arriving in Kuwait. See Shiber, The Kuwait Urbanization, 643; Joe Nasr, "Saba Shiber, 'Mr. Arab Planner': Parcours professionnel d'un urbaniste au Moyen-Orient," Géocarrefour 80, no. 3 (2005), https://doi.org/10.4000/geocarrefour.1175.

${ }_{97}$ Morroe Berger, ed., The New Metropolis in the Arab World (New Delhi: Allied Publishers, 1963); papers prepared for an international seminar on City Planning and Urban Social Problems, Cairo, December 17-22, 1960; see also Asseel Al-Ragam, "Representation and Ideology in Postcolonial Urban Development: The Arabian Gulf," The Journal of Architecture 16, no. 4 (2011): 461, https://doi.org/10.1080/13602365.2011.598702.

98 Al-Ragam, "Representation and Ideology in Postcolonial Urban Development," 460, 463.
} 
that has witnessed one distinct urban form - that dictated by the scale of the car-'graft' itself on the distinct urban matrix and tissue of a tranquil, organic, typical desert Arab city." 99 And again and again Shiber also relied on aerial photography (and cartographic material) to make this point across the several hundred pages of the book.

The comparative aerial perspective stimulated Shiber to critique the 1952 Master Plan and the resulting rebuilding sharply. To him, MSM's plans were "rigid, geometric, twodimensional plans: very simply and truly, drawings-drawings in an era when drawing, or geometry, had become an anathema." ${ }^{100}$ Yet, on the one hand, Shiber argued almost sympathetically with MSM:

Kuwait is unlike most other old Arab cities such as Cairo, Damascus, Baghdad, Jerusalem, Tunis and others in the sense that the old city contained few large religious, historic or architectural structures to act as starting-points or foci to planning. Often, the absence of such landmarks, or constraints, and a total "free rain" in a planning situation can cause challenges to the planner that are unusual, numerous and difficult. How does one create a significant new urban idiom? ${ }^{101}$

Here he conceded that the absence of significant historical landmarks, which would have emerged or protruded in the aerials, posed certain challenges for the new planning process due to the lack of urban orientation. On the other hand, he reproached MSM's planning solutions for obeying the car ad extremum and thereby sacrificing Kuwait's historical morphology and urban fabric:

The old urban pattern, rendered in contemporary idiom, could have easily served as the inspiration for evolving the structure, grain, pattern, matrix, mosaic and texture of the new city. Instead, the almost childish happiness and preoccupation with superhighways, roundabouts and the haphazard, inorganic procedure in the choice of sites for major urban functions misted up basic considerations. ${ }^{102}$

In addition, Shiber criticized that the plan had neglected the climatic demands on architecture and urban planning, and the sociocultural needs of the Kuwaiti people. ${ }^{103}$

Most importantly, for Shiber, the 1960s aerial view of Kuwait City demonstrated that "uncircumscribed spread" had become the oil city's (or petro-urbanism's) dominant characteristic; this had resulted from the indefinite urban expansion beyond the former town wall that the master plan had stimulated. ${ }^{104}$ In combination with the destruction of

\footnotetext{
99 Shiber, The Kuwait Urbanization, 5.

${ }^{100}$ Ibid., 116. More precisely, he explained, "the basic planning of Kuwait, if a few rudimentary geometric lines and labels may be referred to as 'planning,' is not only alien to the habitat of Kuwait and therefore incorrect in the deep meaning of planning principles, but it must have emanated from minds-judging from the inorganicism [sic] of the 'planning'-that were purely the minds of civil engineers and surveyors. Those few lines that represent the 'Plans' of Kuwait could not have been any more rigid and inorganic vis-à-vis Kuwait and the Kuwaiti determinants of city formation." Shiber, The Kuwait Urbanization, 120.

${ }^{101}$ Shiber, The Kuwait Urbanization, 5.

102 Ibid., 118.

${ }^{103}$ Ibid., 115-21.

104 Ibid., 118.
} 
the historic urban core, Shiber arrived at the conclusion that new Kuwait City had failed to acquire a unique identity-which the pre-oil town had had-and that it was still in the process of creating a new urban form for itself. Evidently, a major shift had occurred in that, from a professional perspective at least, pre-oil Kuwait was being appreciated.

This shift came to characterize subsequent disputes over the urban development of Kuwait, like the one that unfolded in The Architects' Journal between Kuwaiti planner Karim Jamal, Ghazi Sultan-the co-owner of Sultan Gallery, architect, and the time the Director of the Master Planning Department-and the British town planning company Colin Buchanan and Partners, who had developed the second master plan of Kuwait in the 1960s. ${ }^{105}$ First Karim Jamal, and later Ghazi Sultan, criticized the initial destruction of Kuwait's pre-oil urban morphology and architecture in the 1950s and accused Colin Buchanan and Partners of continuing the destruction. Similar to Shiber, the Kuwaiti planners used 1951 aerial photographs to contrast and contemplate the violent change induced by the aerial master planning. This debate reveals that the visual representations of pre-oil Kuwait triggered an affectionate mourning for its loss, despite the fact that it was the 1951 aerial photography itself that had been the catalyzer of pre-oil Kuwait's destruction. Although the 1952 Master Plan brought forth a new modern metropolis and thus a new urban face of petro-rich Kuwait, it did not necessarily create a more functional, more socially stimulating environment nor a climatically better adapted habitat.

\subsection{An Aerial View of the Petroleum Playground}

For Kuwait, the circular relationship between spatial visualizations and urban transformations was again sharply experienced during the Iraqi invasion 1990-91. ${ }^{106}$ In Close Up at a Distance: Mapping, Technology \& Politics, Laura Kurgan has described how, by August 1990, the GIS-based satellite image mapping of Kuwait had just produced one of the most detailed visual data sets ever available when the Iraqi army invaded Kuwait to occupy the oil fields. Once that happened, the brand-new aerial images became outdated overnight and suddenly represented "preservation images" from which to rebuild the

\footnotetext{
${ }^{105}$ Karim Jamal, “Kuwait: A Salutary Tale," The Architects' Journal 158, no. 50 (December 1973); Colin D. Buchanan, \& Partners, "Kuwait," The Architects' Journal 159, no. 21 (May 1974); Colin D. Buchanan, \& Partners, "Lifestyle Contrasts and Need for Planning Reform," The Architects' Journal 160, no. 40 (October 1974); Ghazi Sultan, “Kuwait," The Architects' Journal 160, no. 40 (October 1974); Karim Jamal, “Destruction of the Middle East?", The Architects' Journal 164, no. 30 (July 1976). Karim Jamal used a 1951 oblique photograph of the port area and a 1970s one with a similar view in juxtaposition to substantiate his reproach of the "ruthless destruction of the closely packed pattern" of pre-oil Kuwait and of the incoherent "rebuilding" strategy proposed by the 1952 master plan, "as if the country was in ruin or in a desperate situation." See Jamal, "Kuwait," 1453.

${ }^{106}$ Laura Kurgan, Close Up at a Distance: Mapping, Technology, and Politics (New York: Zone Books, 2013), 84-95.
} 
3.15 A GIS-based satellite image of Kuwait City. Advertisement for the software company Intergraph, 1991.

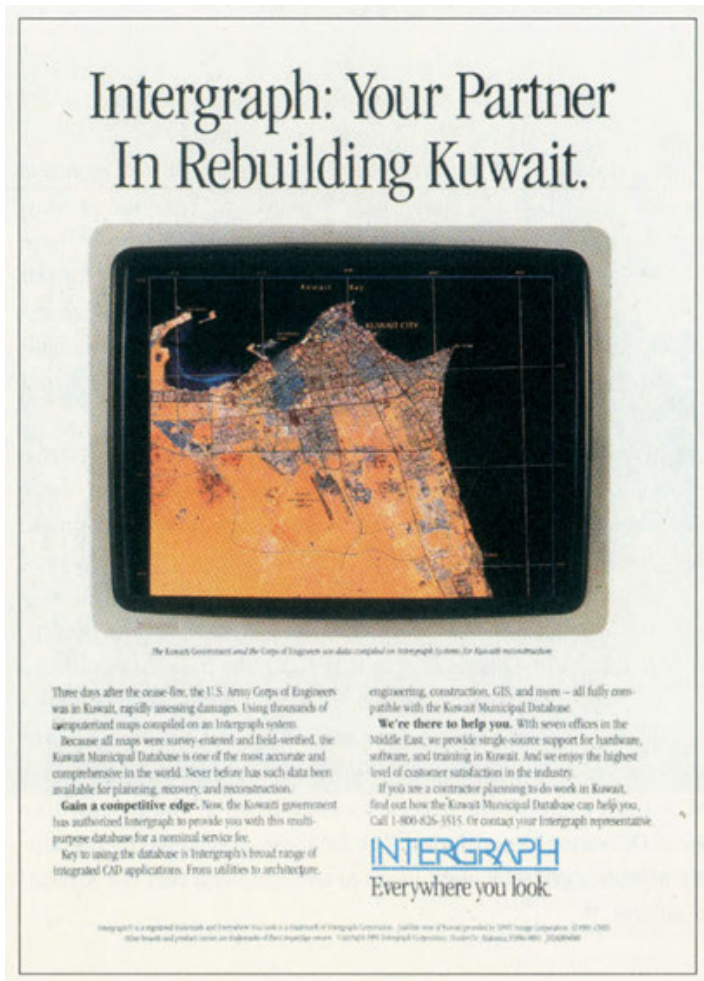

city once the Iraqi army and the US-led coalition forces had left. ${ }^{107}$ Even before the war had ended, the software company Intergraph used the aerial view of Kuwait in the advertisement "Rebuilding Kuwait" (fig. 3.15). This advertisement is oddly reminiscent of Hunting Aerosurveys' adverts at the end of World War II, both in its aesthetic and in its demonstrative belief in the power of aerial omniscience. The proliferation of the view from above is a gesture of power that continues to be fueled in many ways by (the violent quest for) petroleum.

Today, reproductions of the 1951 photomosaic of Kuwait are often found on display in shops, offices, and various institutions in Kuwait, including the reading room of the Center for Research and Studies on Kuwait. The composite photo is not only considered as a historical document, but is also contemplated with affect. The enduring repercussions of the 1950s view from above can be substantiated not only here, but also in contemporary media forms. Images of Kuwait City from above, as seen for example on Google Maps and Google Earth, easily disclose the physical imprint of the 1952 Master Plan's road network (fig. 3.16). Even though MSM's plan required the demolition and hollowing out of the 


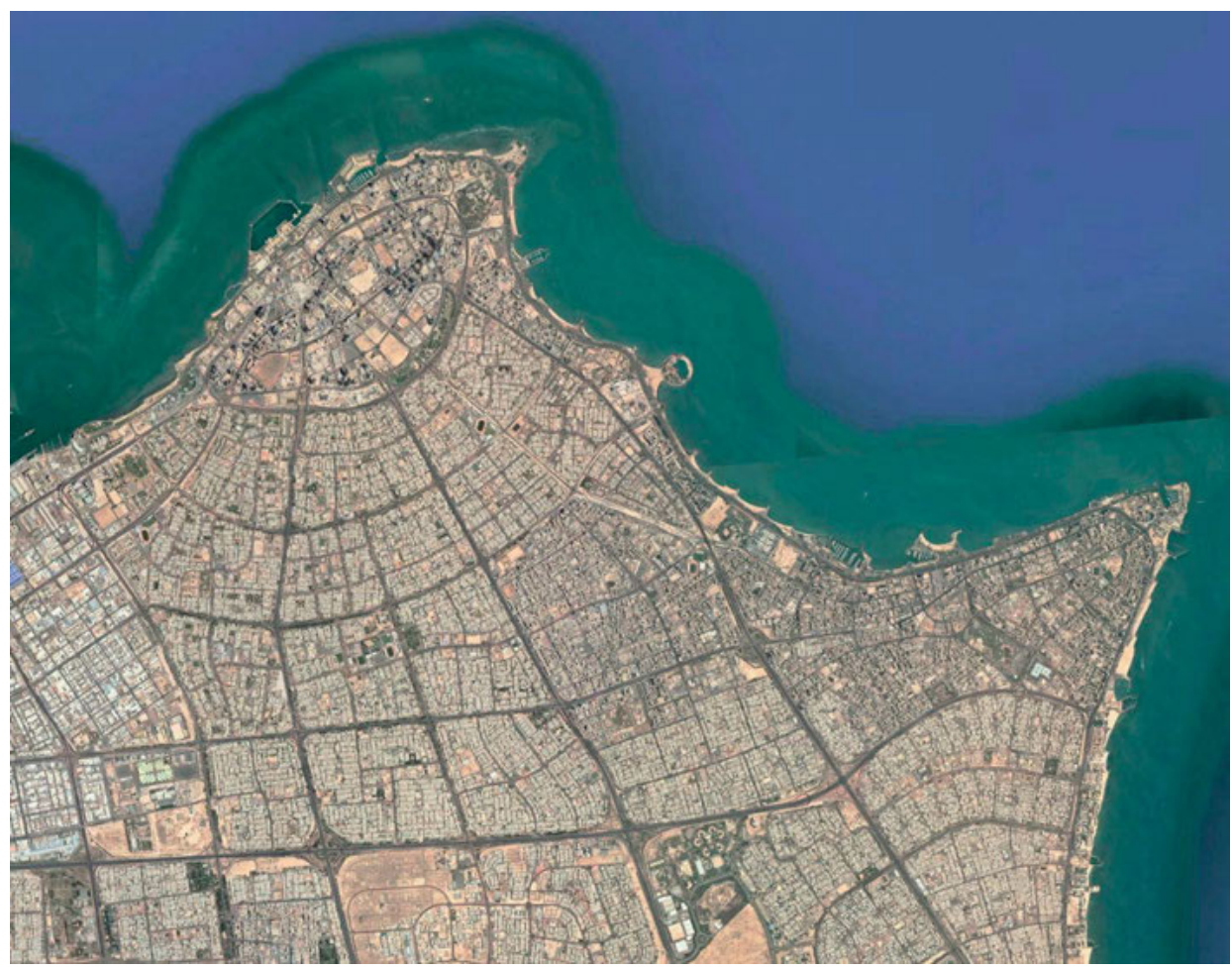

3.16 Composite satellite photograph of Kuwait City. Google Earth Pro 7.3.4.8248. Image taken on July $28,2021$.

pre-oil built-up area, such contemporary imagery is evidence of the fact that the almond shape of Kuwait's pre-oil historic core has remained engrained in the urban texture until the present day (despite several subsequent building booms and the Gulf War).

This assessment, however, is only possible through fossil-fueled technologically enhanced vision and the perpetuated visual representation of such gazing: the 1951 photomosaic, the 1952 Master plan, new cartography, map icons, drone footage, Google Earth, and so forth. Only when viewed from above is the almond-shaped form nested in the wave-like coastal formation recognizable. The fact that this view is acknowledged as iconic of Kuwait City, and by extension of the country, is caused by the continuous proliferation of the aerial view of Kuwait in a myriad of images that, despite all their differences, share a common denominator. Processed through aerial photography, urban planning, and cartography, the starkly simplified urban form of pre-oil Kuwait has become the symbol of the modern oil city, an iridescent symbol that has intrinsically interlinked the past and the present as well as the continuity and the change that has characterized Kuwait's urban transformation. In Kuwait it is not so much the physical urban form itself but rather its (historical) visual representation that allows for an assessment of the past. 
Given the substantial loss of the built environment of pre-oil times, when viewed from above the almond-shaped form can offer traces of historical continuity, of memory, of belonging for 1960s audiences just as for today's.

The plethora of visual evidence has demonstrated the endless loop of visual mappings of Kuwait's space from above and subsequent attempts at assessing, altering, and picturing it anew. What the 1951 aerial imagery of Kuwait was able to depict and how it contributed to constructing meaning for Kuwait City changed rapidly throughout the 1950s. At first, the aerials were symbolic of a modern technology of perception and visualization. They allowed for the visual homogenization and subsequent future vision of transforming space in a kind of magic omniscience that led to the specific form of the 1952 Master Plan. Throughout the long 1950s, while the drawing of future Kuwait City was implemented on the ground, the circulating 1951 aerials (obliques and verticals) remained static images of a Kuwait frozen in May 1951. Only with an aerial update in 1960 were these aerials recognized as outdated and no longer representative of the status quo. They were subsequently used as historical records that encapsulated the pre-oil city, which by that time was already gone on the street level.

Images, especially photographic ones, have the ability to simultaneously realistically represent an object (to capture it in time and space) and to bury it (to freeze it in time and space). Petro-modernity has a similar double character. On the one hand, projections of almost unlimited progress and change at unprecedented speed have come to characterize petro-modernity. On the other, the toxic destruction contained in this progress is tangled up in a myriad of promotional strategies that enables petroleum's toxicity to remain hidden from view. Here, I see the ambiguous iridescence at play.

Is it only the familiarity with the aerial views of (pre-)oil Kuwait that allows us to see the old in the new, like a fleeting imprint of light on the retina? The gaze from above keeps seducing the viewer with its play of distance, of past and present, with its iridescent effect. While such a totalizing, disembodied view is humanly impossible and creates a remote visual dissociation from the urban landscape, it nevertheless also projects a sense of familiarity and of proximity through its aesthetic rendering across many visual representations, as each little detail becomes viewable and feels weirdly tangible. Like a miniature landscape, the town of Kuwait lies at one's feet and becomes available for being played with and altered as one pleases, without feeling affected by these changes oneself. It is a gaze that is confident in having the world subjugated to the pleasure of humans and to the comfort of splashing petroleum - a playground fueled by petro-desires. In contrast, reapproaching the historical photographs from time to time as traces of memory can become a method of nostalgic anachronism against the infectious spill of petromodernity's proliferation of spatial images, which may one day have washed away the last trace of the pre-oil period, and maybe, once the final drop of petroleum has been extracted, even of the oil period. 
